\title{
FAMÍLIA, DIREITOS HUMANOS E HOMOAFETIVIDADE
}

\author{
FAMILY, HUMAN RIGHT AND HOMO-AFFECTIVITY
}

Roberto Hilsdorf Rocha ${ }^{1}$

\begin{abstract}
Resumo:
O presente trabalho trata das uniões homoafetivas e sua relação com os direitos humanos, considerando a necessidade de sua positivação como elemento catalisador no combate à discriminação. $\mathrm{O}$ artigo faz uma ligação entre direito de família e direitos humanos usando a homoafetividade como elo. Pretende demonstrar que o processo de normatização de uniões entre pessoas do mesmo sexo é plenamente compatível com o nosso ordenamento jurídico, tanto nos aspectos formais quanto de conteúdo.
\end{abstract}

Palavras-chave: Direitos Humanos. Família. Hermenêutica Jurídica. Homoafetividade. Igualdade.

\begin{abstract}
:
This study discusses homo-affective relationships and how they relate to human rights, taking into account the need of their validation as a catalytic element as far as the fight against discrimination is concerned. The article makes a connection between Family Law and human rights, using homo-affectivity as a bridge. The present work aims at showing that the process of legalization of marital relationships between people of the same sex is thoroughly compatible with our legal system regarding its formal as well as content aspects.
\end{abstract}

Keywords: Human Rights. Family. Hermeneutic Law. Homo-affectivity. Equality.

\section{Introdução}

A investigação deste estudo foi organizada em torno de três eixos que, não por coincidência, amparou-se sob o prisma da teoria tridimensional de Miguel Reale.

No primeiro eixo - dos fatos - pretendeu o trabalho oferecer uma análise social da homoafetividade, a fim de esclarecer inúmeros equívocos sobre o assunto, sempre envolto em muito preconceito, procurando identificar o papel do Direito no processo de libertação e inclusão desses grupos minoritários à sociedade.

No segundo eixo - dos valores - foram analisados argumentos contrários e favoráveis à institucionalização das uniões homoafetivas, ao mesmo tempo em que se buscou nos princípios norteadores das relações familiares, sempre orientados pela ética dos direitos humanos, o fundamento para o reconhecimento e a superação da discriminação.

\footnotetext{
1 Especialista em Direitos Humanos pela Faculdade de Direito da Universidade de São Paulo.
} 
No terceiro eixo - das normas - com base em iniciativas, experiências e jurisprudência existentes, examinamos a questão sob ponto de vista jurídico, considerandose o ordenamento jurídico nacional e recentes decisões judiciais a respeito do tema.

É de se notar que o tema tem causado muitas controvérsias entre os juristas e operadores do Direito, gerando limitações a um direito tão elementar quanto o direito de ser quem se é. Por entendermos que o Direito é essencialmente político, a presente pesquisa propõe, com seus esclarecimentos, que a normatização, a legalização e a tipificação da união entre pessoas do mesmo sexo, ou, em síntese, a criação de meios para o seu reconhecimento jurídico, seria a melhor forma de ver resolvida esta questão, uma vez que estes relacionamentos - e todas as suas vicissitudes morais, afetivas, políticas e de direito - vêm cada vez mais se impondo em nossa sociedade.

Sem embargo dessa legítima busca, cabe também localizar, numa interpretação atualizada, que a hermenêutica construtiva e humanística pode, desde logo, revelar uma compreensão mais adequada sobre o tema.

A ninguém é dado ignorar que a heterossexualidade não é a única forma de expressão da sexualidade da pessoa humana. A sociedade atual demonstra uma hostilidade frente às pessoas que não são heterossexuais. Elas não têm um respaldo jurídico que legitime a relação entre si e perante a sociedade. Esta possibilidade de união ainda é somente reconhecida entre heterossexuais. E os tantos outros? O Direito, portanto, não pode continuar ignorando nem mesmo negando tal realidade.

O que se pretende, esclarecendo e desvendando o assunto, é fazer valer o direito à igualdade, notadamente em relação à pessoa humana homossexual na sociedade brasileira. Se os indivíduos têm direito à busca da felicidade e de constituir família, não há porque continuar negando ou querendo desconhecer que muitas pessoas só são felizes se ligadas a outras do mesmo sexo. É forçoso reconhecer que estas pessoas só buscam o respeito às suas uniões enquanto parceiros. Respeito e consideração que lhes são devidas pela sociedade e, principalmente, pelo Estado.

A união homoafetiva é instituto que guarda perfeita harmonia com os objetivos fundamentais da República Federativa do Brasil - constitucionalmente garantidos - de construir uma sociedade livre, justa e solidária e promover o bem de todos, sem preconceitos de origem, raça, sexo, cor, idade e quaisquer outras formas de discriminação (art. $3^{\circ}$, I e IV CF).

A sociedade brasileira é dinâmica e plural, abarca uma diversidade de relações. Por força da Constituição que incorpora o princípio da pluralidade, o Direito brasileiro deve acompanhar as mudanças sociais e contemplar, sempre que possível, essa 
diversidade. A união entre pessoas do mesmo sexo vem contemplar apenas um dentre tantos aspectos dessa diversidade que compõe a sociedade brasileira. É mister que se preencha a lacuna jurídica existente, a fim de que se proteja a dignidade da pessoa humana e se promova a visibilidade dessa relação, com o respaldo e respeito de toda a sociedade.

Em toda a sociedade que se diz e se pretende democrática e pluralista, o Direito não pode servir como obstáculo à transformação social que amplie o significado da dignidade humana; pelo contrário, deve ser instrumento de proteção às conquistas e demandas sociais que caminhem neste sentido.

A possibilidade de legalizar a união entre pessoas do mesmo sexo torna viável a reparação de notórias injustiças, como os casos em que o parceiro morre e seu companheiro ou companheira do mesmo sexo é excluído de qualquer participação em um patrimônio que também é seu, pois fruto de trabalho e conquista mútuos, em decorrência de vários anos de convivência.

Relacionamentos pessoais baseados num compromisso recíproco, laços familiares e amizades duradouras são parte da vida de todo ser humano. Eles satisfazem necessidades emocionais fundamentais e provêem segurança e aconchego em horas de crise em vários momentos da vida, inclusive durante a velhice. São um poderoso instrumento contra a falta de raízes, além de proteger e manter a integridade dos indivíduos. Com essa intenção, a relação permanente e compromissada entre homossexuais deve existir como possibilidade legal.

O Brasil é um País no qual os homossexuais, masculinos e femininos, têm sofrido extrema hostilidade. Raras são as semanas que não se sabe de um assassinato violento. Uma das portas que leva à violência é a homofobia. O reconhecimento oficial da homossexualidade, impulsionada pela legalização da união homoafetiva, favorecerá e certamente diminuirá o comportamento homofóbico e conseqüente agressão. A lei, além de aceitar e proteger a realidade, concede um respaldo social importante.

Ao mesmo tempo, a aceitação legal das uniões homoafetivas encorajará mais gays e lésbicas a assumirem sua orientação sexual. Em nenhuma hipótese irá "criar" mais homossexuais. Essa realidade somente tornará mais justa a vida das pessoas que já vivem esta orientação sexual de forma clandestina. A possibilidade de assumir o que se é, tem como conseqüência a diminuição da angústia. O que é proibido gera vergonha, dissimulação e, muitas vezes, medo. A viabilidade da união estável, mesmo que nãoexercida, reduzirá problemas criados pela necessidade de esconder a própria natureza, de não ser reconhecido socialmente, viver em isolamento ou na mentira. 
Além dos problemas comumente atrelados à condição do ser homossexual, e pior, do viver relação homossexual, um vilão silencioso e muito maior é enfrentado pela maioria dos homossexuais: a indiferença hipócrita, os "ouvidos de mercador" e as incessantes "vistas grossas" que as famílias, os amigos e a sociedade em geral impõe com o firme propósito de ignorar a condição homossexual. Ora, as pessoas com orientação homossexual possuem a mesma necessidade de segurança e proximidade que pessoas com orientação heterossexual e devem ter direitos ao mesmo apoio nas relações permanentes.

A possibilidade de oficializar a união entre pessoas do mesmo sexo permitirá, como nas uniões heterossexuais, que, em períodos difíceis, os parceiros possam ser ajudados. Os casais heterossexuais, quando passam por problemas, são auxiliados por várias frentes que, não raramente, culminam em impedir uma ruptura imediata. Situação muito diferente enfrentada pelos homossexuais que, geralmente, mantêm relações secretas, ignoradas pela família e amigos, o que dificulta a busca de ajuda nas situações difíceis ou de crise.

Para percorrer um tema tão amplo, procuramos responder à seguinte pergunta básica: existe o direito fundamental à constituição de família para os homossexuais? Em torno desta questão, outras, essenciais, desdobram-se: o não-reconhecimento pelo Estado das uniões homoafetivas configura uma discriminação de direito? O conceito de família abrange as uniões homoafetivas? A institucionalização das uniões homoafetivas estaria em harmonia com o ordenamento jurídico brasileiro? Como a união entre pessoas do mesmo sexo vem sendo tratada pela jurisprudência e pela legislação nacionais?

Refletindo e respondendo a estas indagações, acreditamos estar expressando os anseios de uma parcela de brasileiros e brasileiras que lutam contra o preconceito e apenas esperam ver reconhecidos seus legítimos direitos humanos.

\section{Os fatos: combatendo preconceitos}

Ao se analisar uma questão cientificamente, é necessário recorrer à terminologia, principalmente quando o assunto a ser estudado é controvertido e envolto em preconceitos, como é o caso do tema do presente trabalho. Por isso, iniciamos nosso estudo procurando saber o que o Direito e as ciências correlatas entendem por homossexualidade. 
Como "normas não existem fora da linguagem, ${ }^{2}$ fomos buscar, primeiro, o conceito em um dicionário da Língua Portuguesa. O Grande Dicionário Larousse Cultural da Língua Portuguesa define homossexualismo como "desvio do desejo, que se orienta para o mesmo sexo, tanto nas fantasias como na relação corporal”.

Já no âmbito jurídico, Plácido e Silva, em seu vocabulário jurídico, define homossexualidade como "Comércio carnal ou prática de atos sexuais entre individuos do mesmo sexo. É inversão sexual, em que o homem serve de mulher para satisfazer a lascivia de outro homem, ou a mulher maneja como homem para provocar o orgasmo em outra mulher e em si própria". E homossexualismo como "indicativo da anormalidade do instinto sexual do individuo, em virtude do que somente tem inclinação sexual ou amorosa para individuos de seu próprio sexo, muitas vezes com repugnância ou aversão aos seres do sexo oposto".

O Dicionário Jurídico, de Maria Helena Diniz, ${ }^{3}$ define homossexualidade como "qualidade daquele que tem atração sexual por indivíduo do mesmo sexo" e homossexualismo como "atração erótica ou sexual que alguém sente por pessoa de seu sexo" e como "prática de ato sexual entre pessoas do mesmo sexo, constituindo uma perversão ou inversão sexual".

Genival Veloso de França na obra Medicina Legal ${ }^{4}$ classifica o homossexualismo como um distúrbio da sexualidade. No mesmo sentido Sutter, ${ }^{5}$ que o classifica como um tipo sexual anômalo.

O que se tem em comum nesses conceitos e classificações é que definem e rotulam a homossexualidade como inversão, desvio ou anomalia, o que, definitivamente, são idéias e conceitos ultrapassados pela Ciência, como se verá a seguir. Não é à-toa, portanto, a dificuldade da maioria da doutrina, até então, em reconhecer as uniões homoafetivas, pois acabam partindo de dados, pressupostos e conceitos absolutamente divorciados da verdade, da complexidade e, sobretudo, da diversidade da natureza humana.

Com o propósito de contribuir para a eliminação do preconceito, inimigo capital da Ciência e de uma Nação que, em tese, é democrática e justa, se faz necessário, então, esclarecer algumas questões elementares acerca da homossexualidade .

\footnotetext{
2 LOPES, José Reinaldo de Lima. As palavras e a lei: direito, ordem e justiça na história do pensamento jurídico moderno. São Paulo: Ed. 34/Edesp, 2004. p. 29.

3 DINIZ, Maria Helena. Dicionário jurídico. São Paulo: Saraiva, 1998.

4 FRANÇA, Genival Veloso de. Medicina legal. 4. ed. Rio de Janeiro: Guanabara Koogan, 1995. p. 161

5 SUTTER, Matilde Josefina. Determinação e mudança de sexo: aspectos médico-legais. São Paulo: Revista dos Tribunais, 1993. p. 139 e ss.
} 
O primeiro equívoco, que deve ser combatido, é o de que a homossexualidade é doença ou anomalia, e que, como tal, pode ser curada. Levando-se em consideração que a homossexualidade não prejudica o raciocínio, a estabilidade, confiabilidade ou aptidões sociais e vocacionais, o Conselho Federal de Medicina em 1985, e a Organização Mundial de Saúde em 1994, excluíram da Classificação Internacional de Doenças o Código 302.0, que até então definia a homossexualidade como "desvio e transtorno sexual".

Na mesma esteira, o Conselho Federal de Psicologia considerando, entre outros aspectos, que a forma como cada um vive sua sexualidade faz parte da identidade do sujeito, a qual deve ser compreendida na sua totalidade, e que a Psicologia pode e deve contribuir com o seu conhecimento para o esclarecimento sobre as questões da sexualidade, permitindo a superação de preconceitos e discriminações, proibiu em 1999, através da edição da Resolução CFP n. 01/99, a colaboração de qualquer psicólogo com eventos e serviços que proponham tratamento e cura das homossexualidades. Querer curar ou modificar um homossexual é, portanto, prática baseada em inadmissível ignorância, constituindo-se verdadeira violência à natureza humana.

Contrapondo às definições mostradas anteriormente, na Enciclopédia de Psicologia Contemporânea, Dorin ${ }^{6}$ define a homossexualidade simplesmente como "atração ou relação sexual entre pessoas do mesmo sexo".

O dicionário Houaiss define homossexualismo como "a prática de relação amorosa elou sexual entre individuos do mesmo sexo" e homossexualidade como "condição homossexual". ${ }^{7}$ São conceitos que deixam de lado termos anacrônicos como desvio de comportamento, doença, comércio carnal, transtorno ou anomalia.

Jurandir Freire Costa, também entende que o argumento de homossexualidade não ser doença ou anomalia, apesar de não suficiente, é um importante fator para a conquista da tolerância, in verbis: "No momento em que todos entenderem que o homossexualismo não é doença, uma perversão ou uma imoralidade, mas um fenômeno tão natural quanto qualquer outro fenômeno sexual, apenas nesse momento é possível que uma grande batalha contra a intolerância tenha sido vencida". ${ }^{8}$

Outra questão que se coloca em relação à terminologia e que tem causado bastante confusão é o termo "opção sexual", o qual entendemos não ser o mais apropriado,

6 DORIN, Lannoy. Enciclopédia de psicologia contemporânea. São Paulo: Iracema, 1977.

7 HOUAISS, Antonio; VILAR, Mauro de Sales. Dicionário Houaiss da Língua Portuguesa. Rio de Janeiro: Objetiva, 2001.

8 COSTA, Jurandir Freire. A inocência e o vício: estudos sobre o homoerotismo. Rio de Janeiro: RelumeDumará, 1992. p. 34. 
uma vez que a homossexualidade em geral não é uma escolha. Do mesmo modo que ninguém escolhe ser heterossexual e apenas se percebe desejando o outro sexo, gays e lésbicas se descobrem do jeito que são em algum momento de suas vidas. Jamais, de um dia para outro, escolhem mudar seus desejos e afetos.

A expressão correta a ser empregada é “orientação sexual”, caracterizada por uma duradoura atração emocional, romântica, sexual ou afetiva para com indivíduos do gênero masculino ou feminino.

Há três orientações sexuais comumente reconhecidas: heterossexual, atração erótica e ou afetiva por indivíduos do sexo oposto; bissexual, atração por ambos os sexos e homossexual, atração por indivíduos do mesmo sexo.

Sendo a orientação sexual um dos componentes da personalidade humana, ela é uma característica perfeitamente natural e o desafio que se impõe é lidar com ela, reconhecendo-a tanto social como juridicamente, afastando de uma vez por todas os preconceitos que ainda insistem em envolver a questão.

Por fim, entendemos que não se deve mais usar a terminologia "homossexualismo", pois esta foi criada no século XIX pela Psiquiatria para designar doença, o que, como vimos, está ultrapassada. O termo mais adequado seria "homossexualidade", que se refere ao modo de ser, comportamento, condição. Não devemos subestimar estas colocações, pois a "inovação verbal pode propor uma inversão nos sinais de valores, tratando o que era mau como bom, ou vice-versa". ${ }^{9}$ E, o que se pretende aqui, é minimizar os estigmas que por tanto tempo assombraram este comportamento.

Oportuno, portanto, esclarecer que a prática da homossexualidade sempre existiu, ${ }^{10}$ e salientar que nem sempre a homossexualidade foi reprimida. Sua prática foi por muito tempo tolerada e aceita socialmente, como na Grécia Antiga, por exemplo, onde um homem que se apaixonasse ou que tivesse relações sexuais com outro era tido como perfeitamente normal. ${ }^{11}$ Desde os tempos mais remotos da História da Humanidade há relatos de sua presença. O antropólogo Luis Mott afirma que "entre os hititas, povo vizinho e inimigo de Israel, havia uma lei autorizando o casamento entre homens (1400 antes de Cristo)". Há relatos de que existam documentos egípcios que datam de 500 anos

\footnotetext{
9 LOPES, José Reinaldo de Lima. As palavras e a lei: direito, ordem e justiça na história do pensamento jurídico moderno. São Paulo: Ed. 34/Edesp, 2004. p. 38.

${ }^{10}$ GREEN, James Naylor. Além do Carnaval: A homossexualidade masculina no Brasil do século XX. Tradução de Cristina Fino e Cássio Arantes Leite. São Paulo: Unesp, 2000. p.194.

11 DOVER, Kenneth James. A homossexualidade na Grécia antiga. Tradução de Luís Sérgio Frausz. São Paulo: Nova Alexandria, 1994. p. 14.
} 
antes de Abraão, relatando práticas homoeróticas. ${ }^{12}$ Ademais, a homossexualidade existe em todas as sociedades. Historiadores relatam que em praticamente todas as sociedades há registros não-só de atos homossexuais como de identidades, comunidades e subculturas homossexuais distintas. Boswell vai mais além e mostra como, em contrapartida à atual visão hipócrita-puritana-simplista de nossa sociedade, as uniões homoafetivas eram institucionalizadas na maioria das antigas sociedades ocidentais:

Recognizing that many - probably most - earlier Western societies institucionalized some form of romantic samesex union gives us a much more accurate view of the immense variety of human romantic relationships and social responses to them than does the prudish pretense that such "unmentionable" things never happened. ${ }^{13}$

No mundo antigo e mesmo na Idade Média, não havia a palavra homossexual, porque não havia este conceito e vice-versa. O fato de alguém praticar "atos" homoeróticos não o enquadrava em uma "identidade". Por exemplo, em Roma, ainda segundo Boswell, ao menos em seus centros urbanos, não distinguia, em sua maior parte, a população gay dos outros e considerava a prática e o interesse homossexuais como uma parte comum do erotismo humano: "Roman society, at least in its urban centers, did not for the most part distinguish gay people from others and regarded homosexual interest and practice as an ordinary part of the range of human eroticism". ${ }^{14}$

Desta forma, podemos concluir que o homossexualismo é uma construção social. Construção essa, não concebida por um acaso, mas para formar e manter um determinado padrão da sociedade.

Adotamos o posicionamento de Folcault que, segundo Sullivan:

(...) via o homossexualismo como apenas uma categoria de opressão social, inextricavelmente ligadas a outras: à maneira como se constrói o sexo em si para privilegiar os homens sobre as mulheres; à maneira como se constrói a raça para oprimir as minorias raciais; à maneira como se constrói a estética, a inteligência e toda uma variedade de coisas que parecem "naturais" a fim de oprimir alguns e controlar outros. ${ }^{15}$

\footnotetext{
${ }_{12}$ MOTT, Luis. O que todo cristão deve saber sobre homossexualidade. Disponível em: http://www.ggb.org. br/cristão.html>. Acesso em: 09 mar. 2000.

${ }^{13}$ BOSWELL, John. Same-sex unions in premodern Europe. New York: Vintage, 1995. p. 282.

14 _. Christianity, social tolerance, and homosexuality. Chicago: The University of Chicago Press, 1981. p. 333 .

${ }^{15}$ SULLIVAN, Andrew. Praticamente normal: uma discussão sobre o homassexualismo. Tradução de Isa Mara Lando. São Paulo: Companhia das Letras, 1996. p. 80.
} 
Assim, o homossexualismo é também uma categoria de opressão, construída socialmente para manter determinado padrão social. É, pois, um fato que se impõe ao Direito e este, por sua vez, em diversos períodos da história em sociedades diferentes procurou ou reprimi-lo, muitas vezes até com a pena de morte, ou adotou uma postura mais indiferente, dependendo como a sociedade se organizava.

Passemos então à análise da opressão e exclusão sofrida pelos homossexuais, correlacionado-as com os outros casos de exclusão, procurando, assim, identificar o papel do Direito no processo de libertação e inclusão desses grupos minoritários à sociedade, uma vez que "a restrição das liberdades de um grupo é a restrição das liberdades de todos". ${ }^{16}$

Acreditamos que, ao se incluir um determinado grupo social à sociedade, se está, mesmo que indiretamente, contribuindo para a inclusão de outros, também excluídos.

Muitos seres humanos no mundo inteiro encontram-se atualmente em estado de opressão, dentre eles as mulheres, os homossexuais, os negros, os deficientes físicos, os índios, os trabalhadores, os desempregados, os miseráveis etc., sendo, portanto, excluídos socialmente, e em alguns casos, excluídos juridicamente, o que significa que lhes são extirpados o direito a ter direitos, ou seja, ausência, parcial ou total, de cidadania. O processo de exclusão desses diferentes segmentos sociais tem sido agravado pela chamada globalização.

Historicamente isto não se deu por acaso. Para Engels, ${ }^{17}$ conforme as sociedades passaram a produzir mais do que era necessário para o próprio sustento, o surgimento da propriedade privada acarretou uma divisão da sociedade em classes desiguais, o que ocasionou, também, uma mudança fundamental nas relações entre homens e mulheres. A divisão de trabalho anterior, com as mulheres como cultivadoras e os homens como caçadores, conferia uma posição privilegiada às mulheres, pois a sociedade dependia primeiramente dos alimentos que elas produziam. Já que a minoria que formava a classe dos proprietários era formada praticamente por homens, o casamento torna-se monogâmico, uma vez que estes buscavam passar as propriedades para seus filhos, e para tanto, necessitavam saber quem eram eles. Era o fim da linhagem materna, ou seja, o

\footnotetext{
16 SULLIVAN, Andrew. Praticamente normal: uma discussão sobre o homassexualismo. Tradução de Isa Mara Lando. São Paulo: Companhia das Letras, 1996. p.138.

${ }^{17}$ ENGELS, Friedrich. A origem da família, da propriedade privada e do Estado. Tradução de Leandro Konder. 12. ed. Rio de Janeiro: Bertrand, 1991.
} 
reconhecimento da descendência através da mãe, e o início da primeira opressão de classe existente na história.

Como ressalva José Reinaldo de Lima Lopes:

Se bem observada, esfera das desigualdades inclui, na perspectiva dos séculos XVII e XVIII, aquilo que virá a ser chamado o espaço da reprodução: servos (trabalhadores) submetem-se ao pai de família da mesma forma que os filhos. Na esfera da família reproduz-se a vida material tanto pela geração da vida quanto pela produção de riqueza. A família é apresentada como núcleo de produção (mesmo em um tempo em que já se começavam a despontar as unidades de produção corporativas, as companhias de comércio e indústria). ${ }^{18}$

Eric Hobsbawm ao comentar o livro Sexo e Poder - A Família no Mundo, 1900-2000, do sociólogo sueco Göran Therborn, sustentou que a ascensão da sociedade capitalista industrial protegeu e reproduziu o patriarcalismo, pois, "A família patriarcal não era apenas 'uma pesada âncora social', mas um mecanismo essencial de empreendimento econômico". ${ }^{19}$

Uma vez que a sexualidade gay desafia a idéia da família heterossexual como único modo de vida possível, e como também desafia a idéia de que o sexo seja possível apenas para a reprodução, a sociedade, então patriarcal, passa a definir o que seja um comportamento sexual "normal", ao mesmo tempo em que cria o "homossexual" como um tipo social.

São sempre os opressores que criam os oprimidos. ${ }^{20}$

Interessante observar que "as primeiras investidas contra a homossexualidade por parte da medicina foram acompanhadas de uma forte preocupação por parte das classes dominantes com quaisquer atividades sexuais extrafamiliares". ${ }^{21} \mathrm{O}$ tipo homossexual criado serviu, portanto, para manter, durante anos, o padrão de uma sociedade individualista, patriarcal, heterossexista, machista e burguesa.

Ora, embora a sexualidade refira-se à mais profunda intimidade do ser, seus mecanismos de repressão encontram-se na esfera social e são exercidos como meio de

\footnotetext{
${ }^{18}$ LOPES, José Reinaldo de Lima. op. cit., p. 186.

19 HOBSBAWM, Eric. Os anos rebeldes. Folha de S.Paulo, Caderno Mais, São Paulo. 19.02.2006, p. 5.

${ }^{20}$ HALLIFAX, Noel. Libertação gay e luta pelo socialismo. Disponível em: <htttp://members.tripod.com/ $\sim$ socialista/textos/homo.html>. Acesso em: 06 jun. 2000.

${ }^{21}$ FRY, Peter; MACRAE, Edward. O que é homossexualidade? 7. ed. São Paulo: Brasiliense, 1991. p. 81.
} 
dominação, ou seja, “a repressão sexual sempre existirá em sociedades onde persistam relações de poder baseadas na exploração". ${ }^{22}$

O Direito, portanto, situa-se aqui, como um dos instrumentos necessários à eliminação de toda e qualquer forma de exploração. Neste sentido, leciona Bacila: “ $O$ que nega o direito - geral, abstrato, para todos - é a estigmatização. Logo, a negação de estigmas é a reafirmação do direito" ${ }^{23}$ E vai mais além: "É necessário, pois, desconstruir para depois construir. Desconstruir estigmas e construir novos modelos sociais baseados em aspectos positivos e dinâmicos. Nesta perspectiva, aceitando-se a negação de estigmas, o direito pode constituir importante fator de auxílio e de sugestão de mudança social". ${ }^{24}$

O mundo continuamente muda. Com o advento da pílula e a disponibilidade de um amplo serviço contraceptivo, a vida familiar dita tradicional transformou-se radicalmente, com o corte do laço até então existente/imposto entre a prática do sexo e reprodução para os heterossexuais, ao mesmo tempo em que o HIV agiu como um catalisador, sem precedentes, para o colapso das normas da discussão pública sobre a homossexualidade.

Neste sentido, como bem ensina e adverte Miguel Reale, devemos nos manter vigilantes às mutações que se operam no mundo, a fim de não escaparem os fatos antecipadores da ordem social; que o Direito deve ser visto em sua concreta historicidade; e que há fatos que exigem sejam encontradas outras soluções normativas, sob pena de se cair no mundo das ficções e dos artifícios na interpretação de regras superadas, sem ofensa dos direitos fundamentais, como os da liberdade. ${ }^{25}$

Considerando que a preocupação dominante do jurista deve ser a de "assegurar a cada homem a liberdade de ser o que é, assim como a fruição daquilo que pode fazer, uma sociedade plural, aberta à compreensão e ao auxílio mútuo", entendemos que, para ser realmente justa, a postura do Direito, além de permissiva, deve também ser libertadora, pois, a Justiça, na realidade, é "uma exigência de ordem feita de liberdade, uma ordem que nasça da composição igual de pendores e vocações diferentes e até mesmo conflitantes, ficando assegurada a cada homem a autonomia de seu ser pessoal'. ${ }^{26}$

\footnotetext{
${ }^{22}$ ARANHA, Maria Lúcia de Arruda; MARTINS, Maria Helena Pires. Filosofando: introdução à filosofia. 2. ed. São Paulo: Moderna, 1993. p. 329.

${ }^{23}$ BACILA, Carlos Roberto. Estigmas: um estudo sobre os preconceitos. Rio de Janeiro: Lumen Juris, 2005. p. 185.

24 Id. Ibid., p. 190.

${ }^{25}$ REALE, Miguel. Estudos de Filosofia e Ciência do Direito. São Paulo: Saraiva, 1978. p. 5, 53 e 55.

${ }^{26}$ Id. Ibid., p. 04.
} 
A luta pela justiça é uma parte essencial da luta pela liberdade, e esta para ser real e concreta deve abranger a luta contra a miséria, o subdesenvolvimento e as grandes desigualdades na repartição dos bens e encargos sociais, ${ }^{27}$ uma minoria deve, para entrar no jogo da associação democrática, procurar a coalizão com outras minorias, atualmente desprezadas e perseguidas, moldando, assim, a promessa de inovações e de saltos qualitativos, não apenas aos grupos minoritários, mas à sociedade inteira, criando, juntas, possibilidades de desempenho em nível mais elevado. ${ }^{28}$ A questão dos homossexuais, das mulheres, dos negros, portadores de deficiências, etc, devem, juntas, ser consideradas como uma verdadeira questão de direitos humanos e justiça social, absolutamente indissociáveis. Clássico exemplo vem da conquista ao direito de votar pelas mulheres que não significou apenas um avanço para o específico grupo das mulheres, mas para a sociedade como um todo.

O Direito que outrora instituiu a escravidão, e que até há bem pouco tempo, considerava as mulheres relativamente incapazes, não pode, ainda hoje, servir de instrumento de opressão às minorias sexuais.

3. Os valores: o afeto como fundamento

Vejamos as manchetes de matérias jornalísticas, envolvendo a temática homossexual:

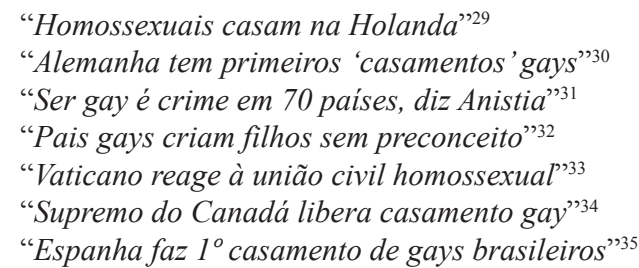

${ }^{27}$ MONTORO, André Franco. Estudos de filosofia do direito. 2. ed. São Paulo: Saraiva, 1995. p. 211.

${ }^{28}$ BOUDON, Raymond; BOURRICAUD, François. Dicionário crítico de sociologia. Tradução de Maria Lúcia Guedes Alcofarado e Durval Ártico. São Paulo: Ática, 1993. p. 349.

29 Folha de S.Paulo, São Paulo, 02.04.2001.

${ }^{30}$ Folha de S. Paulo, São Paulo, 02.08.2001. p. A 13.

31 WASSERMANN, Rogério. Ser gay é crime em 70 países, diz Anistia. Folha de S.Paulo, São Paulo, 23.06.2001. p. A 10 .

32 BIANCARELLI, Aureliano. Pais gays criam filhos sem preconceito. Folha de S.Paulo, São Paulo, 31.03.2002. p. C 18.

${ }^{33}$ Folha de S.Paulo, São Paulo, 29.07.2003. p. A 12

${ }^{34}$ Folha de S.Paulo, São Paulo, 10.12.2004. p. A12.

${ }_{35}$ BURGOS, Patrícia. Espanha faz $1^{\circ}$ casamento de gays brasileiros. Folha de S.Paulo, 14.02.2006, p. A11. 
"Milhares protestam em Madri contra casamento gay"36

"Gay família'é maioria na parada de SP" ${ }^{37}$

A simples análise superficial de tais manchetes, por si só, conduzem à reflexão acerca de como a homossexualidade é valorada diferentemente, evidenciando e apontando fatos que vêm consolidar a igualdade plena até mesmo às jurídicas aberrações de considerar-se a homossexualidade como crime. E de como, apesar de muitos avanços, ainda há resistência de parte da sociedade.

No Brasil, a questão assume um nível intermediário, pois, apesar da homossexualidade não ser considerada um crime os homossexuais ainda estão longe de serem tratados de maneira igualitária e justa, considerando que ainda são impedidos de usufruir direitos elementares, como, por exemplo, o direito ao legítimo reconhecimento de constituição de família.

Interessante notar que, apesar disso, conforme a última das manchetes citadas anteriormente, a maioria dos gays e lésbicas que participaram da Parada do Orgulho Gay, de 2005, em São Paulo, tinham relacionamentos estáveis, que perduravam por mais de dez anos, alguns, inclusive, com filhos, conforme pesquisa realizada pelo Centro LatinoAmericano em Sexualidade e Direitos Humanos, em parceria com a Associação da Parada e com as Universidades Cândido Mendes, USP e Unicamp.

Fato é que, apesar de existentes uniões entre pessoas do mesmo sexo, ainda não há total respaldo e reconhecimento, do ponto de vista jurídico. Tal fato, em um país onde o maior programa de distribuição de renda tem a família até no nome - o "Bolsa-Família" - assume dimensões absolutamente relevantes. Não-reconhecer as uniões homoafetivas como entidade familiar, significa também a exclusão deste grupo a inúmeros direitos, como, por exemplo, financiamento de casa própria, a própria inclusão em programas de distribuição de renda, como já foi dito, alimentos, direitos sucessórios, previdenciários e tantos e muitos outros.

Não resta dúvida que essa situação se deve à maneira pela qual as uniões homoafetivas são ou foram valoradas pela sociedade brasileira, pois influenciam o legislador, a jurisprudência e a própria doutrina.

\footnotetext{
${ }^{36}$ Terra - Notícias. Disponível em: <http://noticias.terra.com.br/mundo/interna/0,,OI558482-EI294,00html>. Acesso em: 18 jun 2005.

${ }^{37}$ GÓIS, Antônio; TÓFOLI, Daniela. Gay família é maioria na parada de SP. Folha de S.Paulo, São Paulo, 16.06.2006, p. C6.
} 
Passemos então a analisar a família e as relações homoafetivas sob o enfoque da moralidade. Para Leonardo Boff existe uma dualidade entre ética e moral. ${ }^{38}$ Moral, do latim mos, mores, designa os costumes e as tradições. Ethos - ética em grego - designa morada humana. Ético significa, portanto, "tudo aquilo que ajuda a tornar o ambiente para uma moradia saudável: materialmente sustentável, psicologicamente integrada e espiritualmentefecunda". Ensina o teólogo, ainda, que na ética há o permanente (necessidade do ser humano de ter uma morada) e o mutável (estilo com que cada grupo constrói sua morada). Quando o permanente e o mutável se unem, surge uma ética verdadeiramente humana. Já moral é sempre plural. Existem muitas morais. O que é imoral para um grupo, para outro pode não-ser. Todas as morais devem estar a serviço da ética. Existem sistemas morais que não se modificam por séculos. A homofobia da sociedade atual, por exemplo. Por sua própria natureza, a moral se realiza como um sistema fechado. A ética abre esse sistema, "Está atenta às mudanças históricas, às mentalidades e às sensibilidades cambiáveis, aos novos desafios derivados das transformações sociais". Enquanto que a moral representa um conjunto de atos, repetidos, tradicionais, consagrados, muitas vezes impensados, a ética confere "a ousadia de assumir, com responsabilidade, novas posturas, de projetar novos valores, não por modismo, mas como serviço à moradia humana". É preciso, portanto, agir com ética, ou seja, abertos a valores que ultrapassam aqueles do sistema tradicional ou de alguma cultura determinada, abertos a valores que abriguem a totalidade de seres humanos (e não-só dos heterossexuais), como os valores do respeito, da defesa da vida, da igualdade, da dignidade da pessoa humana e da solidariedade.

Segundo Ernest Tugendhat:

(...) a moral do respeito universal e igualitário é a única moral que pode ter uma pretensão plausível de realizar a idéia de um ser humano bom (parceiro da cooperação). Nisto está implicado que o comportamento moral consiste em reconhecer o outro como sujeito de direitos iguais; ${ }^{39}$

Aética é também considerada a disciplina que investiga a moral, que, segundo Ronald Dworkin, pode ser "convencional (segundo a qual as regras morais se fundam em convenções)" ou "crítica (em que as regras morais devem ser submetidas a certos crivos da razão)". "A moral de uma sociedade democrática é crítica, e não simplesmente

\footnotetext{
${ }_{38}$ BOFF, Leonardo. A águia e a galinha: uma metáfora da condição humana. 30. ed. Patrópolis: Vozes, 1999. p. 90 e ss.

39 TUGENDHAT, Ernest. Lições sobre ética. Tradução grupo de doutorandos do curso de pós-graduação em filosofia da Universidade do Rio Grande do Sul. Petrópolis: Vozes, 1996. p. 362.
} 
tradicional, ou apoiada na maioria". ${ }^{40}$ Ora, o Estado brasileiro é democrático (art. $1^{\circ}$, da $\mathrm{CF}$ ), portanto, é sob esta perspectiva racional é que passaremos a analisar a família.

"A família é um fenômeno universal e, na qualidade de instituição dinâmica, não está em crise, mas em transformação" ${ }^{41}$ Desta forma, antes de mais nada, é preciso encontrar um conceito contemporâneo de família, ${ }^{42}$ pois, a era da família codificada e patriarcal, inserida em um contexto legal representativo da tríade formada pelo liberalismo, pelo individualismo e pelo patrimonialismo, está superada - uma vez que excludente - e deve ser substituída por um novo paradigma, onde, acreditamos, os laços afetivos devam ganhar maior relevância e se sobressaiam sobre os outros. Neste sentido, Giselda Maria Fernandes Novaes Hironaka: "Hoje, as relações de afeto, ao que parece, caminham à frente nos projetos familiares e, por isso, conduzem à assunção da responsabilidade pela constituição das famílias". ${ }^{43}$

Mirian Freire Pereira assim conceituou família:

Família é um grupo social formado por indivíduos que não ou se consideram consangüíneos uns dos outros por descenderem de um tronco ancestral comum, advindos ounão do casamento e pelos estranhos que nesse grupo forem admitidos por adoção. ${ }^{44}$

Adauto Suannes, identificando a família como base da estrutura social e sede da plenitude do bem estar do ser humano, define família como sendo uma expressão que deve abranger pelo menos aquelas duas pessoas que se unem com o propósito de manutenção desse vínculo afetivo, independente de serem de sexo diverso, tenham ou-não prole. ${ }^{45}$ No mesmo sentido, Maria Berenice Dias:

${ }^{40}$ LOPES, José Reinaldo de Lima. O direito ao reconhecimento para gays e lésbicas. Revista Internacional de Direitos Humanos, a. 2, n. 2, , p. 69 e 70.

${ }^{41}$ MOTTA, Carlos Dias. Uma teoria geral dos princípios jurídicos aplicada ao direito matrimonial. 2003. p. 347. Tese (Doutorado) - Faculdade de Direito, Universidade de São Paulo, São Paulo.

${ }^{42}$ Como bem observa José Sebastião de Oliveira: “O estudo dos fundamentos da família é o estudo da própria sociedade tal qual estruturada no momento histórico, econômico e cultural respectivo. Ela influencia, altera e é alternada numa eterna reação sem fim, refletindo e atribuindo valores fundamentais à sociedade, daí então a inegável importância de ser estudada na evolução do seu conceito" (OLIVEIRA, José Sebastião de. Fundamentos constitucionais do direito de família. São Paulo: Revista dos Tribunais, 2002. p. 355).

${ }^{43}$ HIRONAKA, Giselda Maria Fernandes Novaes. Família e casamento em evolução. Revista do Advogado, São Paulo, n. 62, p. 16-24, mar. 2001. p. 19.

44 PEREIRA, Mirian Freire. As inovações constitucionais no direito de família. 1993. 258 f. Dissertação (Mestrado) - Faculdade de Direito, Universidade de São Paulo, São Paulo. p. 10-11.

${ }^{45}$ SUANNES, Adauto. Concubinato e homossexualismo. Revista Literária de Direito, São Paulo, n. 15, jan./fev. 1997 
Agora o que identifica a família não é nem a celebração do casamento, nem a diferença de sexo do par ou o envolvimento de caráter sexual. O elemento distintivo da família, que a coloca sob o manto da juridicidade, é a identificação de um vínculo afetivo, a unir as pessoas, gerando comprometimento mútuo, solidariedade, identidade de projetos de vida e propósitos comuns ${ }^{46}$

E continua:

se a prole ou a capacidade procriativa não são essenciais para que o relacionamento de duas pessoas mereça proteção legal, não se justifica deixar ao desabrigo do conceito de família a convivência entre pessoas do mesmo sexo". Conclui dizendo: "passando, duas pessoas ligadas por um vínculo afetivo, a manter uma relação duradoura, pública e contínua, como se casados fossem, formam um núcleo familiar à semelhança do casamento, independente do sexo a que pertencem. ${ }^{47}$

Quanto à função, Giselle Câmara Groeninga afirma que "a finalidade da família é a de proteção física e psíquica, dada pela qualidade de desamparo inerente ao ser humano", ${ }^{48}$ e vai mais além: "a família tem como finalidade propiciar o desenvolvimento no ser humano de sua capacidade de pensamento em sintonia com os sentimentos". ${ }^{49}$

Segundo José Sebastião de Oliveira a família é também um meio de realização pessoal dos seus membros, potencializando o desenvolvimento deles e tem como função, entre outras, a assistência moral e psicológica, com o apoio de seus integrantes nos embates de vida. ${ }^{50}$

Assim, podemos, sinteticamente, conceituar família sendo como a reunião de duas ou mais pessoas, unidas pelo vínculo do afeto com o objetivo de mútua assistência.

Percebe-se com essa definição, que a função procriativa da família deixou de ser essencial. Hodiernamente, não teria sentido deixar de fora o casal estéril, ou os que por opção não quiserem ter filhos, e mesmo os casais homossexuais. ${ }^{51} \mathrm{O}$ vínculo de afeto e

\footnotetext{
46 DIAS, Maira Berenice. Novos tempos, novos termos. Disponível em: < http://www.mariaberenice.com.br/site/ content.php?cont id=467\&isPopUp=true>. Acesso em: 04 out 2006.

${ }^{47}$ DIAS, Maira Berenice. União homossexual: o preconceito e a justiça. Porto Alegre: Livraria do Advogado, 2000.

${ }^{48}$ GROENINGA, Giselle Câmara; PEREIRA, Rodrigo da Cunha (Org.). Direito da família e psicanálise: rumo uma nova epistemologia. Rio de Janeiro: Imago, 2003. p. 136.

49 Id. Ibid., p. 137.

${ }^{50}$ OLIVEIRA, José Sebastião de. op. cit., p. 361.

51 “A função procriante, como essência da família, é desmentida pelo grande número de casais sem filhos, por livre escolha, pelo fenômeno dos singles (os que preferiram viver só), pela crescente facilidade de adoção e
} 
a função assistencial se sobressaem sobre os outros, e passam a ser elementos definidores da família atual.

Encontrado o conceito, busquemos agora os principais princípios jurídicos ${ }^{52}$ que devem orientar as relações familiares.

Importante esta busca, pois os princípios jurídicos são os alicerces do Direito. E, os princípios constitucionais, por sua vez, são verdadeiras regras-mestras do sistema jurídico nacional, produzindo efeitos na interpretação das normas e na aplicação do Direito. São dotados de supremacia na ordem jurídica, ou seja, encontram-se em posição hierárquica superior a todas as outras; portanto, toda atividade estatal, seja ela, administrativa, legislativa ou judiciária, deve voltar-se para cumprimento das metas fixadas pela Constituição.

Dentre os princípios constitucionais, há de se destacar a "dignidade humana" (art. $1^{\circ}$, inciso III da CF). Ao lado deste, encontra-se o da promoção do bem do todos, assegurando o constituinte, portanto, o direito à felicidade, entendido este como a forma livre de condução da vida do indivíduo dentro de seu contexto social. ${ }^{53} \mathrm{E}$, "de todos os princípios anunciados, o princípio da dignidade humana e o da promoção do bem de todos merecem nossa maior atenção, quer pelo seu alcance, quer pela sua clareza". ${ }^{54}$

A dignidade da pessoa humana é, portanto, um dos principais princípios constitucionais que orientam a construção e a interpretação do ordenamento jurídico brasileiro. Segundo os ensinamentos de José Afonso da Silva, "é um valor supremo que atrai o conteúdo de todos os direitos fundamentais do homem, desde o direito à vida" ${ }^{55}$

Assim, a família é voltada à realização do princípio da dignidade da pessoa humana. ${ }^{56}$ Roger Raup Rios sustenta que "o estabelecimento de relações homossexuais, fundadas no afeto e na sexualidade, de foram livre e autônoma, sem qualquer prejuízo a terceiros, diz respeito à proteção da dignidade humana". ${ }^{57}$

pela queda progressiva do número de filhos". Paulo Luiz Netto Lobo citado por OLIVEIRA, José Sebastião de. op. cit., p. 271.

52 “Temos que princípios jurídicos são normas jurídicas, positivadas ou não, projetando valores e traduzindo idéias que informam o sistema jurídico e ao mesmo tempo são dele extraídas, cuja aplicação deve ocorrer na maior medida possível e na menor oposição possível a outros princípios e regras jurídicas, em busca da harmonia dos valores da segurança jurídica e da justiça". (MOTTA, Carlos Dias. op. cit., p. 342).

${ }^{53}$ ARAÚJO, Luiz Alberto David. A proteção constitucional do transexual. São Paulo: Saraiva, 2000. p. 71 e ss.

${ }^{54}$ Id. Ibid., p. 101.

${ }_{55}$ SILVA, José Afonso da. Curso de direito constitucional positivo. 16. ed. São Paulo: Malheiros, 1999.p. 93.

${ }^{56}$ MOTTA, Carlos Dias. op.cit., p. 347.

${ }^{57}$ RIOS, Roger Raupp. A homossexualidade no Direito. Porto Alegre: Livraria do Advogado/Esmafe, 2001. p. 111 . 
José Reinaldo de Lima Lopes leciona que, sobre o conceito de dignidade, existem duas principais linhas de entendimento, uma substantiva, e outra procedimental.

A primeira entende a dignidade como um valor, como um status social a ser atingido, ou seja, prescreve que certas maneiras de ser podem ser mais ou menos dignas. Tal entendimento gera a divisão da sociedade em estratos: das pessoas com mais ou menos dignidade, sendo que, as que têm menos dignidade, são tratadas, muitas vezes, com condescendência e paternalismo.

Já o segundo entendimento da dignidade, o procedimental, oriunda de Kant, chama de dignidade tudo o que não tem preço, tudo o que não pode ser trocado. Nesse sentido, "a dignidade é um reflexo da liberdade de cada um, ou seja, da consideração de que cada um é capaz de agir como sujeito, como fim em si mesmo e para si mesmo, e de internalizar criticamente regras, máximas, imperativos, leis de decisão". ${ }^{58}$

Ser humano, portanto, é ser livre, autônomo, consciente. Liberdade essa, não doada como mera caridade, mas construída no dia-a-dia, no tecer dos laços sociais. $\mathrm{O}$ respeito à liberdade de todos traz, como reflexo, uma sociedade mais horizontal e menos autoritária. $\mathrm{O}$ direito à liberdade, à autonomia das pessoas, passa a ser um ponto estratégico e fundamental na elaboração da doutrina dos direitos humanos.

Diante destas informações, fica claro que questões relativas à orientação sexual $^{59}$ estão intimamente ligadas com a proteção à dignidade da pessoa humana. Neste sentido Roger Raupp Rios: "O respeito aos traços constitutivos fundamentais da individualidade de cada um, sem depender de orientação sexual, é ordenado juridicamente em virtude do art. $1^{\circ}$, inciso III, da Constituição, de $1988 " .{ }^{60} \mathrm{E}$ assim fundamenta:

De fato, ventilar-se a possibilidade de desrespeito ou prejuízo a alguém, em função de sua orientação sexual, seria dispensar tratamento indigno ao ser humano. Não se pode simplesmente, ignorar a condição pessoal do indivíduo, legitimamente constitutiva de sua identidade pessoal (na qual, sem sombra de dúvida, se inclui a orientação sexual), como tal aspecto não tivesse relação com a dignidade humana. ${ }^{61}$

\footnotetext{
${ }^{58}$ LOPES, José Reinaldo de Lima. Direitos humanos e tratamento igualitário: questões de impunidade, dignidade e liberdade. Revista Brasileira de Ciências Sociais, São Paulo, v. 15, n. 42, p. 77-100, dez. 2005.

59 Vide página 15 deste trabalho.

${ }^{60}$ RIOS, Roger Raupp. op. cit., p. 91.

61 Id. Ibid., p. 92.
} 
Como a orientação sexual é um dos componentes da personalidade humana, entendemos ser também o direito à livre orientação sexual um direito personalíssimo. Nos dizeres de Luiz Edson Fachin:

Principiando desse modo, pode ser localizada, a partir do
texto constitucional brasileiro que assegura a liberdade,
a igualdade sem distinção de qualquer natureza (art. $5^{\circ}$
da Constituição Federal, de 1988), a inviolabilidade da
intimidade e vida privada (art. $5^{\circ}$, inciso X), a base jurídica
para a construção do direito à orientação sexual como
direito personalíssimo, atributo inerente e inegável da
pessoa humana. Assim, como direito fundamental, surge um
prolongamento de direitos da personalidade imprescindíveis
para a construção de uma sociedade que seja livre, justa e
solidária. ${ }^{62}$

O direito de ser o que se é, o direito de ser ou-não gay ou lésbica, é um direito inerente a qualquer cidadão e deve ser tutelado pelo Estado, uma vez que este para ser democrático deve atentar para a multiplicidade de vontades, tendências e individualismo presentes em seu seio, ou seja, "presume a possibilidade de permitir que a minoria (ou minorias) atinja seus objetivos, sob o predomínio da vontade majoritária". ${ }^{63}$

Ademais e reafirmando o que foi dito acima, sendo a sexualidade um componente inerente à vida, pertence aos direitos da personalidade, entendendo estes como sendo os direitos subjetivos da pessoa defender o que lhe é próprio, ou seja, a identidade, a liberdade, a sociabilidade, a reputação, a honra, etc., compreendendo-se, portanto, direitos considerados absolutos e essenciais à pessoa humana. E como tais, são irrenunciáveis, inalienáveis, intransmissíveis e imprescritíveis. ${ }^{64}$

Desta forma, podemos concluir que o direito à orientação sexual é um direito humano fundamental. Nesse sentido, Maria Berenice Dias afirma que "A garantia da cidadania passa pela garantia da expressão da sexualidade, e a liberdade de orientação sexual insere-se como uma afirmação dos direitos humanos" ${ }^{65}$

Intrinsecamente ligados ao princípio da dignidade da pessoa humana, a Constituição elencou outros que também orientam as famílias. São eles: princípio da nãodiscriminação, da liberdade e da igualdade. Concordamos assim com Paulo Luiz Netto quando diz: "A família moderna parte de dois princípios básicos, de conteúdo mutante

\footnotetext{
${ }^{62}$ FACHIN, Luiz Edson. Elementos críticos do direito de família. Rio de janeiro: Renovar, 1999. p. 94-95.

${ }^{63}$ ARAÚJO, Luis Alberto David. op. cit., p. 100

${ }^{64}$ Id. Ibid., p. 9 e ss.

${ }^{65}$ DIAS, Maira Berenice. União homossexual: o preconceito \& a justiça. cit., p. 16.
} 
segundo as vicissitudes históricas, culturais e politicas: a liberdade e igualdade" ${ }^{66} \mathrm{E}$ com Álvaro Villaça Azevedo quando afirma: “a alma da família é o ser humano, que não pode ser desrespeitado e que tem o direito natural de viver no lar, sem discriminações" ${ }^{67}$

A Constituição em seu art. $3^{\circ}$, inciso IV, proíbe quaisquer formas de discriminação em seu art. $5^{\circ}$, caput, consagra os princípios da igualdade e da liberdade. Desta forma, as regras são o não-discriminar, a igualdade entre os seres e a liberdade das pessoas.

Segundo Flávia Piovesan, no que tange à concepção de igualdade, existem três vertentes: a) a igualdade formal, perante a lei; b) igualdade material, orientada pelo critério socioeconômico e c) igualdade material, correspondente ao ideal de justiça enquanto reconhecimento de identidades (igualdade orientada pelos critérios gênero, orientação sexual, idade, raça, etnia e demais critérios). ${ }^{68}$

Para Boaventura de Souza Santos somente a exigência do reconhecimento e da redistribuição permite a realização da igualdade: "Temos o direito a ser iguais quando a nossa diferença nos inferioriza; e temos o direito a ser diferentes quando a nossa igualdade nos descaracteriza. Daí a necessidade de uma igualdade que reconheça as diferenças e de uma diferença que não produza, alimente ou reproduza desigualdades". ${ }^{69}$

Assim, pode haver discriminações legítimas, só que, para tanto, é necessário que exista uma justificativa razoável, e essa razoabilidade, é, sem dúvida, valorativa. Robert Alexy: "De todo esto se infere que tiene que haber uma razón suficiente para las justificaciones, que las justifique y que la cualificacion de la razón como suficiente es un problema de valoración". ${ }^{70}$ Ora, uma moral crítica não admite que laços afetivos baseados no respeito mútuo, que causem bem-estar aos envolvidos e que não prejudique terceiros, seja considerado como uma coisa ruim.

No mesmo sentido, Celso Antônio Bandeira de Mello:

as discriminações são recebidas como compatíveis com a cláusula igualitária apenas e tão-somente quando existe um vínculo de correlação lógica entre a peculiaridade diferencial acolhida por residente no objeto, e a desigualdade de tratamento em função dela conferida, desde que tal

\footnotetext{
${ }^{66}$ Citado por OLIVEIRA, José Sebastião de. Fundamentos constitucionais do direito de família. São Paulo: Revista dos Tribunais, 2002.

${ }^{67}$ AZEVEDO, Álvaro Villaça de. Estatuto da família de fato. São Paulo: Jurídico Brasileira, 2001. p. 526-527.

${ }^{68}$ PIOVESAN, Flávia. Direitos humanos e o direito constitucional internacional. 7. ed. rev. ampl. e atual. São Paulo: Saraiva, 2006. p. 179.

${ }^{69}$ Citado por Id. Ibid., p. 180.

${ }^{70}$ ALEXY, Robert. Teoria de los derechos fundamentales. Madrid: Centro de Estudios Constitucionales, 1997.
} 
correlação não seja incompatível com interesses prestigiados na Constituição. ${ }^{71}$

Nos dizeres de Luiza Cristina Fonseca Frischeisen:

Afirmar a igualdade entre as pessoas não significa ignorar suas diferenças intrínsecas ou escolhidas como o pertencimento a uma determinada comunidade étnica ou grupo social, gênero, orientação sexual ou opção religiosa, mas não permitir que estas diferenças sejam fundamento para negar o acesso a bens e direitos considerados universais em uma determinada sociedade. ${ }^{72}$

Uma das questões mais debatidas nos últimos anos em torno da proibição da discriminação diz respeito à forma em que sua violação pode ser reparada; concretamente, o tema que preocupa de forma insistente são os efeitos de uma sentença da jurisdição constitucional que anule uma norma por ser discriminadora.

Miguel Carbonell afirma que: "En algunos casos, el efecto de esa sentencia puede ser el de extender el supuesto de la norma a sujetos hasta entonces irrazonablemente excluidos de ella; en otros puede llevar a la simple anulación de la norma, retirando un derecho o prerrogativa que había sido reconocido de forma discriminatoria". ${ }^{73}$

Ademais, não basta apenas proibir atos discriminatórios, é necessário que se promova a libertação de grupos excluídos. Nesse sentido, Joaquim Barbosa Gomes:

Numa palavra, não basta proibir, é preciso também promover, tornando rotineira a observância dos princípios da diversidade e do pluralismo, de tal sorte que venha a operar-se uma transformação no comportamento e na mentalidade dos membros da sociedade, cujos "mores" são fortemente condicionados pela tradição, pelos costumes, pela história. ${ }^{74}$

Desta forma, considerando que a orientação sexual não retira do indivíduo sua capacidade afetiva nem intelectual, e faz parte integrante de sua personalidade, qualquer discriminação legal ou fática que leve em consideração essa condição é inconstitucional e

\footnotetext{
${ }^{71}$ MELLO, Celso Antônio Bandeira de. Conteúdo jurídico do princípio da igualdade. 3. ed. São Paulo: Malheiros, 2006. p. 17.

72 FRISCHEISEN, Luiza Cristina Fonseca. Construção da igualdade e o sistema de justiça no Brasil: alguns caminhos e possibilidades. 2004. Tese (Doutorado) - Faculdade de Direito, Universidade de São Paulo, São Paulo.p. 28.

73 CARBONELL, Miguel. Estudio preliminar. La igualdad y los derechos humanos. El principio constitucional de igualdad. Lecturas de introducción. México: Comisión Nacional de Los Derechos Humanos, 2003. p. 17.

${ }^{74}$ GOMES, Joaquim B. Barbosa. Ação afirmativa e princípio constitucional da igualdade. (O Direito Como Instrumento de Transformação Social. A Experiência dos EUA). Rio de Janeiro: Renovar, 2001. p. 44.
} 
proibida. Incompatíveis com os interesses do Estado brasileiro em se construir uma nação fraterna, pluralista e sem preconceitos. Deve a lei, portanto, observar estes preceitos e promover a igualdade tanto do ponto de vista formal, quanto do material.

Quanto à liberdade, da mesma forma, qualquer restrição que se pretenda, deve ser adequadamente justificada. E, como vimos, em relação aos homossexuais, não existe essa justificativa racional.

Por todo o exposto, percebe-se que no reconhecimento das relações familiares, o afeto e a solidariedade é que devem dar sentido e orientação, e não-tradições, muitas vezes excludentes e injustas.

4. As normas: antigos paradigmas, novos caminhos

Nos capítulos anteriores analisamos a homossexualidade enquanto fato social, bem como os valores e princípios que permeiam a família e as uniões homoafetivas. Resta-nos, agora, a análise do que diz o nosso ordenamento e os caminhos pelos quais tem trilhado o Direito.

A família é tratada em vários documentos internacionais de direitos humanos.

A Declaração Universal dos Direitos Humanos em seu art. XVI proclama que homens e mulheres têm o direito a contrair matrimônio e fundar uma família, sem quaisquer restrições. Considera também a família como núcleo natural e fundamental da sociedade, com a merecida proteção, tanto da própria sociedade como do Estado.

Na mesma esteira, no art. 23, O Pacto Internacional dos Direitos Civis e Políticos reconhece a família como elemento natural e fundamental da sociedade, assegurando, a todos, o direito à constituição de família.

Tão importante a proteção da família, que a Convenção Americana de Direitos Humanos (Pacto de San José da Costa Rica) o assegura em seu art. 17, dispondo, no 27, que este direito jamais será suspenso, nem mesmo em caso de guerra, de perigo público, ou de outra emergência.

O direito à constituição de família é, indubitavelmente, um direito humano fundamental e o direito de família, pode ser considerado como o mais humano dos direitos.

Entretanto, um direito tão elementar e fundamental com a realização do matrimônio e a constituição de família, tem sido negado a milhões de seres humanos 
simplesmente por serem "diferentes" da maioria. Pessoas homossexuais se vêem cotidianamente impedidas de contrair matrimônio e de constituir família.

Nota-se que de todos os documentos citados, asseguram ao homem e à mulher a constituição de família, mas nenhum determina que o casamento deve ser realizado somente entre eles. A diferenciação dos sexos, para esses documentos, é irrelevante. Os únicos requisitos são a vontade e a maioridade.

Ora, um documento sobre direitos humanos jamais deve ser interpretado de modo a restringir direitos. Ao contrário, a interpretação deve sempre ampliar os direitos. Vale lembrar, também, da existência dos princípios da máxima efetividade das normas constitucionais, referentes aos direitos e às garantias fundamentais como, também, à primazia dos direitos humanos. ${ }^{75}$ Segundo estes princípios, as garantias fundamentais devem ter a máxima efetividade e os direitos humanos devem se sobrepor aos demais. Sendo assim, estas normas se inserem na legislação complementar ordinária, representam um limite e, ao mesmo tempo, uma orientação, tanto no momento da exegese quanto no da aplicação do Direito. ${ }^{76}$

A Constituição brasileira, por sua vez, cuida da família em seu art. 226, afirmando ser esta a base da sociedade e impondo-lhe proteção especial do Estado.

Uma leitura menos atenta deste artigo poderia conduzir ao equivocado entendimento de que a Constituição não reconhece as uniões homoafetivas quando, no $\S$ $3^{\circ}$, fala em homem e mulher.

Entretanto, o art. 226 deve ser analisado de forma sistemática, em harmonia com os princípios e fundamentos enunciados pela própria Constituição que, desde seu preâmbulo, estabelece que o Estado brasileiro foi criado para assegurar, dentre outros, o direito à liberdade e à igualdade como valores supremos de uma sociedade pluralista e sem preconceitos. Assim, as entidades familiares vislumbradas no art. 226 são meramente exemplificativas e não-taxativas. Como poderia a Constituição impedir a pluralidade social almejada em seu preâmbulo logo em sua base que é a família? Seria um contrasenso. Portanto, qualquer interpretação diferente é discriminatória, conduta esta, como vimos no capítulo anterior, proibida pela própria Constituição. Assim, o caput do art. 226

\footnotetext{
${ }^{75}$ PIOVESAN, Flávia. Reforma do Judiciário e Direitos Humanos. In: TAVAREZ, André Ramos; LENZA, Pedro; ALARCÓN, Pietro de Jesus Lora (Orgs.). Reforma do Judiciário: analisada e comentada. São Paulo: Método, 2005. p. 70.

${ }^{76}$ REALE, Miguel. op cit., p. 63.
} 
"é, conseqüentemente, cláusula geral de inclusão, não sendo admissivel excluir qualquer entidade que preencha os requisitos de afetividade, estabilidade e ostensibilidade". ${ }^{77}$

O direito de constituição de família, que é de todos, deve, em uma sociedade justa, democrática e igualitária, ser exercido por todas as pessoas, independente de sua orientação sexual. E assim ocorrendo, interessante fenômeno concretiza-se: modifica-se a família, que é a base, e se modificará toda a sociedade, tornado-a muito mais justa e solidária.

Partindo-se do pressuposto que a família é a base de toda organização social, a maneira pela qual ela se estrutura traz necessariamente reflexos em toda a sociedade. Ora, se pretendemos uma sociedade mais justa, fundamental transformá-la em sua base, tornado-a inclusiva. Considerando os fundamentos do Estado (art. $1^{\circ} \mathrm{CF}$ ), os objetivos fundamentais da República (art. $3^{\circ} \mathrm{CF}$ ) e os princípios emancipadores espalhados por todo corpo constitucional, mas principalmente os constantes no art. $5^{\circ}$, não faz o menor sentido organizar a família baseado em critérios excludentes. E, como bem afirma Luiza Frischeisen, dentre os caminhos para a construção da igualdade, a interpretação constitucional é um deles. ${ }^{78}$

Esclarece Sérgio Resende de Barros:

No Brasil, ainda mais, porque a enumeração feita pelo Constituinte no artigo 226 e seus parágrafos não veio como numerus clausus para fechar a evolução do Direito de Família, mas sim como numerus apertus a todas as entidades familiares que - existentes diante do direito constitucional da família brasileira - por ele não podem ser ignoradas de nenhum modo, se não ainda na legislação, ao menos por ora na jurisprudência e na doutrina constitucionais. ${ }^{79}$

E vai mais além: "os direitos humanos repelem a exclusão de quaisquer entidades familiares verificáveis na evolução da família humana" ${ }^{80}$ Aliás, o mesmo autor tem uma brilhante visão sobre a estreita ligação entre direito de família e direitos humanos que vale ser apreciada:

${ }^{77}$ LÔBO, Paulo Lins Netto. Entidades familiares constitucionalizadas: para além do numerus clausus. In: III CONGRESSO BRASILEIRO DE DIREITO DE FAMÍLIA. Família e cidadania: o novo CCB e a vacatio legis. Belo Horizonte: Del Rey, 2002. p. 95.

78 FRISCHEISEN, Luiza Cristina Fonseca. op cit., p. 112.

${ }^{79}$ BARROS, Sérgio Resende de. Direitos humanos da família: dos fundamentais aos operacionais. In: GROENINGA, Giselle; PEREIRA, Rodrigo da Cunha (Org.). Direito da família e psicanálise: rumo uma nova epistemologia. Rio de Janeiro: Imago, 2003. p. 154.

${ }^{80}$ BARROS, Sérgio Resende de. op. cit., p. 154. 
É por esse enlaçamento afetivo maior - visando a construir a humanidade pela força maior da solidariedade humana em cuja origem está a solidariedade familiar - que se amarram entre si, inseparavelmente, os direitos humanos e os direitos de família, a principiar do próprio direito fundamental à família, que - a mais e acima de estar lastreado em todos os direitos fundamentais da humanidade - também tem por lastro o direito maior de todos os direitos humanos: o direito à humanidade. ${ }^{81}$

O atual Código Civil brasileiro, por sua vez, trata do casamento nos arts. 1.511 ao 1.590. Em nenhum proíbe expressamente o casamento entre pessoas do mesmo sexo. É certo, porém, que em alguns deles como, por exemplo, o 1.517, há referência em "homem e mulher". Contudo, a leitura e aplicação de tais dispositivos não obriga ou implica que deva, necessariamente, haver a diversidade sexo para a sua celebração. Quisesse o legislador brasileiro enveredar por caminho diverso, o teria feito como o Código Civil português que, de forma expressa no art. 1.577 dispõe que o casamento ocorre entre duas pessoas de sexo diferentes.

De acordo com o atual Código Civil brasileiro, a semelhança de sexos também não é impedimento para a celebração do casamento, nem causa de nulidade ou anulabilidade.

Diante da falta de proibição legislativa, a doutrina majoritária construiu a teoria da inexistência do casamento. Em outras palavras, a maioria da doutrina criou a idéia de que a diversidade de sexo é pressuposto de existência do casamento.

Nesse sentido, Álvaro Villaça Azevedo: "Todo sistema regulador do casamento civil acolhe a diversidade de sexo como seu pressuposto existencial". ${ }^{82}$ E Luiz Fernando do Vale de Almeida Guilherme: "A legislação brasileira não faz referência expressa à diversidade de sexos para o casamento, mas é a diversidade de sexo uma das características mais importantes para a validade do casamento civil". ${ }^{83}$ Aduz o citado Autor, ainda, que esta é também a posição de Caio Mário e Maria Helena Diniz e que, diversamente, Silvio Rodrigues é um dos que entendem que o casamento entre pessoas do mesmo sexo acarreta a nulidade e não-inexistência. Sustenta Silvio Rodrigues sua posição

\footnotetext{
81 Id. Ibid., p. 150.

82 AZEVEDO, Álvaro Villaça de. Estatuto da família de fato. São Paulo: Jurídico Brasileira, 2001. p. 467.

${ }^{83}$ GUILHERME, Luiz Fernando do Vale de Almeida. União estável entre homossexuais no direito brasileiro e no direito comparado. Revista da Escola Paulista de Magistratura, São Paulo, ano 4, n. 2, p. 150-171, jul./ dez. 2003.
} 
afirmando que a teoria da inexistência poderia trazer insegurança jurídica, conduzir à bigamia e prejudicar o cônjuge de boa-fé. ${ }^{84}$

Tendo em vista os princípios constitucionais expostos no capítulo anterior e, em que pese a posição destes respeitados juristas, acreditamos que estes entendimentos não devem prosperar, devendo as teorias da inexistência e da invalidade serem descontraídas.

O casamento nada mais é do que um negócio jurídico, definido por Pablo Stolze como sendo: "a declaração de vontade, emitida em obediência aos seus pressupostos de existência, validade e eficácia, com o propósito de produzir efeitos admitidos pelo ordenamento jurídico pretendidos pelo agente. ${ }^{85}$

Segundo o mesmo Autor, seus requisitos de existência são: a) manifestação de vontade; b) agente emissor da vontade; c) objeto (utilidade física ou ideal); d) forma.

Ora, mesmo sendo com pessoas do mesmo sexo, no que se refere ao casamento, todos estes requisitos encontram-se presentes.

E, quanto à nulidade do casamento, como já explicitado, não há previsão no Código Civil, de que a semelhança de sexo implica como uma de suas causas. Quanto aos negócios jurídicos em geral, são requisitos de validade: a) manifestação de vontade livre e de boa-fé; agente emissor da vontade capaz e legitimado para o negócio; objeto lícito, possível e determinado (ou determinável); d) forma adequada (livre ou legalmente prescrita). A princípio, também todos o requisitos estão presentes. Deve-se, entretanto, analisá-los, caso a caso, assim como nos casamentos heterossexuais.

Poder-se-ia argumentar que, em relação ao casamento entre pessoas do mesmo sexo, o objeto seria ilícito ou imoral. Ora, desde a primeira Constituição Republicana que a homossexualidade deixou de ser crime no Brasil. E, como bem demonstramos no capítulo anterior, não há nada de imoral em relacionamentos afetivos, mesmo que formados por pessoas do mesmo sexo.

Assim, não há de se falar, nem em inexistência, nem invalidade de casamentos entre pessoas do mesmo sexo. Somente uma tradição excludente e o mero e injustificável preconceito permeiam e explicam a resistência de muitos em reconhecer o óbvio, ou seja, que o ordenamento jurídico brasileiro não-só possibilita o reconhecimento das uniões homoafetivas com perfil de entidade familiar como, também, não proíbe expressamente a celebração do casamento entre pessoas do mesmo sexo. E, se não-proíbe, conseqüentemente, permite.

\footnotetext{
${ }^{84}$ MOTTA, Carlos Dias. op. cit., p. 222.

${ }^{85}$ GAGLiAnO, Pablo Stolze. Novo curso de direito civil. 7. ed. São Paulo: Saraiva, 2006. p. 352.
} 
Negar que pessoas do mesmo sexo realizem matrimônio é tão absurdo quanto negar a realização do matrimônio inter-racial ou entre brasileiros e estrangeiros, pois inexiste, como nesses casos, nexo causal entre a peculiaridade diferencial acolhida e a desigualdade de tratamento em função dela conferida. "O direito personalíssimo à orientação sexual conduz a afastar a identificação social e jurídica das pessoas por esse predicado" ${ }^{86}$ Flagrante, portanto, é a inconstitucionalidade desta proibição.

Conforme bem leciona Fábio Konder Comparato "o caráter geral da lei supõe uma igualdade absoluta dos cidadãos, tanto em sua votação quanto em sua destinação". ${ }^{87}$

Se a Constituição proíbe, como admitir que a própria lei discrimine? Se discriminações de fato são sempre odiosas, o que há de ser dito de uma verdadeira discriminação de direito? Se o próprio Estado comete discriminação, como impedir que a sociedade o cometa?

O que se espera é apenas a não-intervenção estatal, apenas o reconhecimento do Estado da possibilidade de união e constituição familiar, de forma igualitária. Nem mesmo igualdade formal, que é a maneira mais simples da aplicação deste princípio, os homossexuais conseguiram. Assim, o elementar direito de ser tratado com igualdade perante a lei continua sendo, em pleno século XXI, ainda uma reivindicação necessária e legítima do movimento gay.

A doutrina também não é unânime e já se ouvem vozes mais progressistas como, por exemplo, a de Ana Carla Harmatiuk Matos:

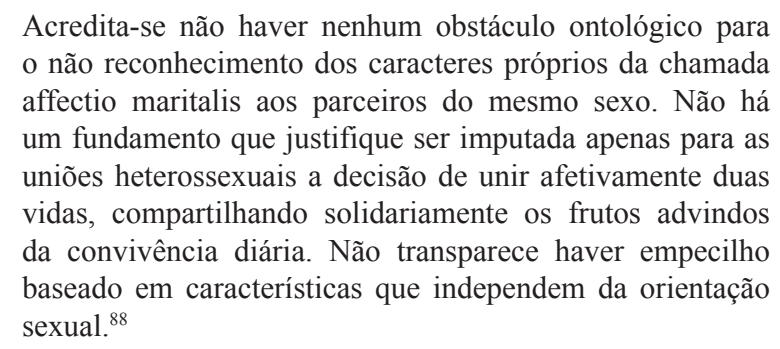

Por sua vez, as decisões judiciais, em sua maioria, acompanham o entendimento ainda majoritário e não reconhecem as uniões homoafetivas como entidade familiar. Entretanto, a fim de se evitar o enriquecimento ilícito, consideram as relações

\footnotetext{
${ }^{86}$ FACHIN, Luiz Edson. Elementos críticos do direito de família. Rio de Janeiro: renovar, 1999. p. 95.

${ }^{87}$ COMPARATO, Fábio Konder. Direito público e privado. São Paulo: Saraiva, 1996. p. 49.

${ }^{88}$ MATOS, Ana Carla Harmatuik. União entre pessoas do mesmo sexo: aspectos jurídicos e sociais. Belo Horizonte: Del Rey, 2004. p. 65.
} 
entre pessoas do mesmo sexo como sociedade de fato, protegendo os direitos patrimoniais. Retiram da relação seus aspecto afetivo e a reduzem a mera relação quase que comercial. De companheiros, são considerados pela "justiça", apenas como sócios. Alguns arestos citamos, escolhidos entre àqueles que acreditamos ser os mais interessantes e pertinentes, respeitada a ordem cronológica:

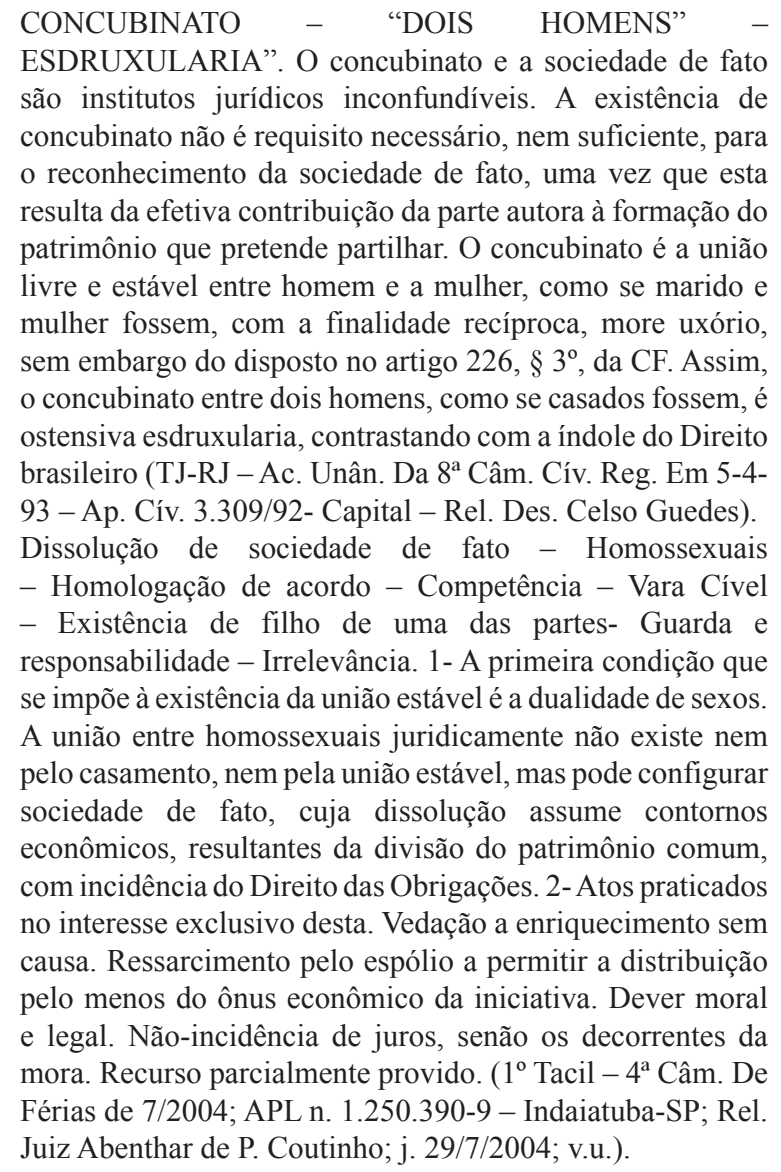

O que estas decisões têm em comum é que as respectivas fundamentações baseiam-se apenas em questões patrimoniais e obrigacionais, admitindo certos direitos apenas para se evitar o enriquecimento ilícito.

Como observou o ministro Sálvio de Figueiredo Teixeira no Recurso Especial n. 148.897 - MG (97.0066124-5) Quarta Turma (DJ, 06.04.1998): “Com efeito, embora permeadas as colocações com aspectos de relacionamento afetivo e amoroso, 
de convivência humana, de busca da felicidade, as causas de pedir e os pedidos estão vinculados ao Direito Obrigacional".

É preciso, portanto, demonstrar o esforço comum para se efetivar a meação, pressuposto, que, em uma relação heterossexual, não é necessário. Esquecem totalmente da dignidade - aquilo que não tem preço, que não se troca - fundamento primordial da Constituição da República.

O direito aos alimentos e outros decorrentes das relações familiares são absolutamente negados.

Algumas decisões, como se observou anteriormente, chegam a adjetivar as relações homoafetivas de esdrúxulas, e outras consideram irrelevante a questão da guarda de menor, o que, constitucionalmente, deveria ser prioridade por se tratar de interesse da criança e do adolescente. Afastam a interpretação analógica e, sobretudo, sistemática, ignorando a Lei de Introdução ao Código Civi1 ${ }^{89}$ ao não-admitir o instituto da união estável às pessoas do mesmo sexo, como se o art. $1.723^{90}$ do Código Civil não fizesse parte do ordenamento e não submetesse aos ditames constitucionais da não-discriminação, da liberdade e da igualdade.

Renegam, assim, a autonomia dos cidadãos que são livres para fazer o que quiserem desde que não prejudiquem a vida alheia. Aliás, longe de prejudicar, estes cidadãos, estão sim, ao se unirem, dando demonstrações explícitas de solidariedade, de união, de junção em busca de bem comum.

Este entendimento restrito e injusto está sendo modificado pela Justiça. Já é possível encontrar, no Tribunal de Justiça do Rio Grande do Sul, decisões que incluem a homoafetividade no âmbito familiar. Assim, o Tribunal de Justiça gaucho, encontra-se na vanguarda em relação aos demais Tribunais brasileiros, estabelecendo uma estreita ligação entre direitos humanos e família.

Utilizando-se de uma interpretação analógica, atualizada, sistematizada e humana, as leis reguladoras do relacionamento entre um homem e uma mulher, enquanto não exista uma legislação específica, passam a ser aplicadas às relações homoeróticas. Agindo assim, o Judiciário está cumprindo o seu verdadeiro papel que é o "de formular, segundo determinados procedimentos de que participa a comunidade de intérpretes, os

\footnotetext{
${ }_{89}$ Art. $4^{\circ}$ - Quando a lei for omissa, o juiz decidirá o caso de acordo com a analogia, os costumes e os princípios gerais do Direito.

90 Art. 1.723 - É reconhecida como entidade familiar a união estável entre o homem e a mulher, configurada na convivência pública, contínua e duradoura e estabelecida com o objetivo de constituição de família.
} 
valores compartilhados, bem como o de servir de canal de expressão para grupos que demandem a promoção dos objetivos comuns expressos pelos direitos fundamentais". ${ }^{91}$

HOMOSSEXUAIS. UNIÃO ESTÁVEL. POSSIBILIDADE JURIDICA DO PEDIDO. É possível o processamento e o reconhecimento de união estável entre homossexuais, ante princípios fundamentais esculpidos na constituição federal que vedam qualquer discriminação, inclusive quanto ao sexo, sendo descabida discriminação quanto à união homossexual. É justamente agora, quando uma onda renovadora se estende pelo mundo, com reflexos acentuados em nosso pais, destruindo preceitos arcaicos, modificando conceitos e impondo a serenidade cientifica da modernidade no trato das relações humanas, que as posições devem ser marcadas e amadurecidas, para que os avanços não sofram retrocesso e para que as individualidades e coletividades, possam andar seguras na tão almejada busca da felicidade, direito fundamental de todos. Sentença desconstituída para que seja instruído o feito. Apelação provida. (Apelação Cível n. 598362655, Oitava Câmara Cível, Tribunal de Justiça do RS, Relator: José Ataídes Siqueira Trindade, Julgado em 01/03/2000).

APELAÇÃO. UNIÃO HOMOSSEXUAL. RECONHECIMENTO DE UNIÃO ESTÁVEL. PARTILHA. Embora reconhecida na parte dispositiva da sentença a existência de sociedade de fato, os elementos probatórios dos autos indicam a existência de união estável. PARTILHA. A união homossexual merece proteção jurídica, porquanto traz em sua essência o afeto entre dois seres humanos com o intuito relacional. Caracterizada a união estável, impõe-se a partilha igualitária dos bens adquiridos na constância da união, prescindindo da demonstração de colaboração efetiva de um dos conviventes, somente exigidos nas hipóteses de sociedade de fato. NEGARAM PROVIMENTO. (Segredo de Justiça) (Apelação Cível n. 70006542377, Oitava Câmara Cível, Tribunal de Justiça do RS, Relator: Rui Portanova, Julgado em 11/09/2003)

RELAÇÃO HOMOSSEXUAL. UNIÃO ESTÁVEL. PARTILHA DE BENS. Mantém-se o reconhecimento proferido na sentença da união estável entre as partes, homossexuais, se extrai da prova contida nos autos, forma cristalina, que entre as litigantes existiu por quase dez anos forte relação de afeto com sentimentos e envolvimentos emocionais, numa convivência more uxoria, pública e notória, com comunhão de vida e mútua assistência econômica,

${ }^{91}$ MACIEL, Débora Alves; KOERNER, André. Sentidos da judicialização da política: duas análises. Lua Nova, São Paulo, n. 57, p. 113-133, 2002. 
sendo a partilha dos bens mera conseqüência. Exclui-se da partilha, contudo, os valores provenientes do FGTS da ré utilizados para a compra do imóvel, vez que "frutos civis", e, portanto, incomunicáveis. Precedentes. Preliminar de não conhecimento do apelo rejeitada. Apelação parcialmente provida, por maioria. (Segredo de Justiça) (Apelação Cível n. 70007243140, Oitava Câmara Cível, Tribunal de Justiça do RS, Relator: José Ataídes Siqueira Trindade, Julgado em 06/11/2003).

É também do Rio Grande do Sul a decisão que permite, inclusive, a adoção por casais homossexuais:

\begin{abstract}
APELAÇÃO CÍVEL. ADOÇÃO. CASAL FORMADO POR DUAS PESSOAS DE MESMO SEXO. POSSIBILIDADE. Reconhecida como entidade familiar, merecedora da proteção estatal, a união formada por pessoas do mesmo sexo, com características de duração, publicidade, continuidade e intenção de constituir família, decorrência inafastável é a possibilidade de que seus componentes possam adotar. Os estudos especializados não apontam qualquer inconveniente em que crianças sejam adotadas por casais homossexuais, mais importando a qualidade do vínculo e do afeto que permeia o meio familiar em que serão inseridas e que as liga aos seus cuidadores. É hora de abandonar de vez preconceitos e atitudes hipócritas desprovidas de base científica, adotandose uma postura de firme defesa da absoluta prioridade que constitucionalmente é assegurada aos direitos das crianças e dos adolescentes (art. 227 da Constituição Federal). Caso em que o laudo especializado comprova o saudável vínculo existente entre as crianças e as adotantes. NEGARAM PROVIMENTO. UNÂNIME. (SEGREDO DE JUSTIÇA) (Apelação Cível n. 70013801592, Sétima Câmara Cível, Tribunal de Justiça do RS, Relator: Luiz Felipe Brasil Santos, Julgado em 05/04/2006)
\end{abstract}

Aliás, no que se refere à adoção, a única questão realmente pertinente e imprescindível de atenção é sobre o bem-estar da criança. O sexo e a orientação sexual dos adotantes é, em verdade, irrelevante.

Neste sentido, Roger Raupp Rios:

a proibição de adoção fundada exclusivamente na homossexualidaderevelaausência de fundamentaçãoracional suficiente para a imposição de um critério discriminatório, 
proceder que afronta, gravemente, o princípio constitucional da igualdade". ${ }^{92}$

Quanto aos direitos previdenciários, o STJ em decisão paradigmática (REsp n. 395904/RS - Recurso Especial 2001/0189742-2 - Rel. Min. Hélio Quaglia Barbosa DJ 06/02/2006 - p. 365), concedeu pensão por morte ao companheiro de relacionamento homoafetivo. Entende o STJ:

\author{
RECURSO ESPECIAL. DIREITO PREVIDENCIÁRIO. \\ PENSÃO POR MORTE. RELACIONAMENTO \\ HOMOAFETIVO. POSSIBILIDADE DE CONCESSÃO \\ DO BENEFÍCIO. MINISTÉRIO PÚBLICO. PARTE \\ LEGÍTIMA. \\ (...)
}

5 - Diante do $\S 3^{\circ}$ do art. 16 da Lei n. 8.213/91, verifica-se que o que o legislador pretendeu foi, em verdade, ali gizar o conceito de entidade familiar, a partir do modelo da união estável, com vista ao direito previdenciário, sem exclusão, porém, da relação homoafetiva.

6- Por ser a pensão por morte um benefício previdenciário, que visa suprir as necessidades básicas dos dependentes do segurado, no sentido de lhes assegurar a subsistência, há que interpretar os respectivos preceitos partindo da própria Carta Política de 1988 que, assim estabeleceu, em comando específico: “Art. 201- Os planos de previdência social, mediante contribuição, atenderão, nos termos da lei, $\mathrm{a}:[\ldots] \mathrm{V}$ - pensão por morte de segurado, homem ou mulher, ao cônjuge ou companheiro e dependentes, obedecido o disposto no $\S 2^{\text {o". }}$.

7 - Não houve, pois, de parte do constituinte, exclusão dos relacionamentos homoafetivos, com vista à produção de efeitos no campo do direito previdenciário, configurando-se mera lacuna, que deverá ser preenchida a partir de outras fontes do direito.

8 - Outrossim, o próprio INSS, tratando da matéria, regulou, através da Instrução Normativa n. 25 de 07/06/2000, os procedimentos com vista à concessão de benefício ao companheiro ou companheira homossexual, para atender a determinação judicial expedida pela juíza Simone Barbasin Fortes, da Terceira Vara Previdenciária de Porto Alegre, ao deferir medida liminar na Ação Civil Pública n. 2000.71.00.009347-0, com eficácia erga omnes. Mais do que razoável, pois, estender-se tal orientação, para alcançar situações idênticas, merecedoras do mesmo tratamento.

9 - Recurso Especial não provido.

92 RIOS, Roger Raupp. A homossexualidade no Direito. Porto Alegre: Livraria do Advogado/Esmafe, 2001. p. 140 
Tendência do STJ de se estender direitos às relações homoafetivas é confirmada pela decisão transcrita abaixo:

PROCESSO CIVIL E CIVIL - PREQUESTIONAMENTO-
AUSENNCIA-SÚMULA282/STF-UNIÃOHOMOAFETIVA-
INSCRIÇÃO DE PARCEIRO EM PLANO DE ASSISTENCIA
MÉDICA - POSSIBILIDADE - DIVERGENCIA
JURISPRUDENCIAL NÃO-CONFIGURADA.
- Se o dispositivo legal supostamente violado não foi
discutido na formação do acórdão, não se conhece do
recurso especial, à míngua de prequestionamento.
- A relação homoafetiva gera direitos e, analogicamente
à união estável, permite a inclusão do companheiro
dependente em plano de assistência médica.
- O homossexual não é cidadão de segunda categoria. A
opção ou condição sexual não diminui direitos e, muito
menos, a dignidade da pessoa humana.
- Para configuração da divergência jurisprudencial é
necessário confronto analitico, para evidenciar semelhança
e simetria entre os arestos confrontados. Simples transcrição
de ementas não basta.(Resp 238715/RS; Recurso Especial
1999/0104282-8 - Relator Min. Humberto Gomes de
Barros - 3a Turma. Julgamento: 07/03/2006. Publicação:
02/10/2006).

No campo legislativo encontram-se atualmente no Congresso Nacional três projetos de lei que disciplinam a união entre pessoas do mesmo sexo. O primeiro, de n. 1.151/95, apresentado pela então deputada Marta Suplicy (PT/SP), originariamente intitulado de união civil, foi depois substituído pela comissão especial, e passou a se chamar parceria civil registrada. O segundo, de n. 52/99, apresentado pelo então deputado Roberto Jefferson (PTB/RJ), cria o pacto de solidariedade entre pessoas, excluindo, assim, a sexualidade da discussão, mas possibilitando que os homossexuais também sejam beneficiados, caso o projeto venha a ser aprovado e sancionado.

Ambos os projetos propõem direito à herança e à sucessão, direitos aos benefícios previdenciários, direito ao seguro saúde em conjunto e à declaração conjunta do Imposto de Renda, direito à nacionalidade no caso de estrangeiros e, por fim, a consideração conjunta para compra de imóvel.

Também em ambos, não se propõem a dar status de casamento ao contrato, usar sobrenome do outro, mudar de estado civil durante sua vigência, constituir família e adotar crianças como casal.

As únicas diferenças de um e outro, além do nome, é que no pacto de solidariedade há a previsão de que um pactuante seja dependente do outro para efeitos de 
passaporte, e estende o direito aos separados de firmarem o pacto, sendo que na parceria só é permitida aos solteiros, viúvos e divorciados.

Mais recentemente foi apresentado pela deputada Laura Carneiro (PFL/RJ) o projeto de Lei n. 6.874/2006 que visa alterar o atual Código Civil acrescentando a este, o art. 839-A, e o parágrafo único ao art. 1.790. Pretende o projeto inserir na legislação, as uniões homoafetivas que se constituiriam por meio de contrato, além do que estender aos homossexuais direitos relativos à sucessão. Textualmente, o projeto:

“Art. 1. ${ }^{\circ}$ Esta Lei altera a Lei n. 10.406, de 10 de janeiro de 2002, para dispor sobre o contrato de união homoafetiva. Art. 2. ${ }^{\circ}$ Acrescente à Lei $n$. 10.406, de 10 de janeiro de 2002, o seguinte capítulo e respectivo artigo.

Capitulo XVIII- A Do contrato de união homoafetiva Art. 839-A. Duas pessoas do mesmo sexo poderão constituir união homoafetiva por meio de contrato em que disponham sobre suas relações patrimoniais.

Parágrafo único. É assegurado, no juizo cível, o segredo de justiça em processos relativos a cláusulas do contrato de união homoafetiva.

Art. 3. ${ }^{\circ}$ Acrescente ao art. 1.790 da Lei n. 10.406, de 10 de janeiro de 2002, o seguinte parágrafo:

Parágrafo único. As disposições desse artigo, aplicam-se, no que couber, aos companheiros homossexuais.

Art. 4. ${ }^{\circ}$ Esta lei entra em vigor na data de sua publicação."

Há também a proposta de Emenda à Constituição n. 70/03, apresentada pelo senador Sérgio Cabral (PMDB-RJ) visando à previsão da união estável entre pessoas do mesmo sexo. Segundo esta proposta, o parágrafo $3^{\circ}$ do art. 226 da CF teria a seguinte redação:

$\S 3^{\circ}$. Para efeito da proteção do Estado, é reconhecida a união estável entre casais heterossexuais ou homossexuais como entidade familiar, devendo a lei facilitar a sua conversão em casamento quando existente entre o homem e a mulher.

Em que pesem as melhores intenções dos ilustres legisladores, entendemos que para a melhor técnica bastaria, tanto para as normas constitucionais, como para as infraconstitucionais referentes às questões familiares, que se substituíssem os substantivos "homem e mulher" por "pessoas". Assim agindo, os legisladores acabariam de uma vez por todas com os estigmas legais relacionados à homoafetividade, suprimir-se-iam as interpretações restritivas da lei, e incluir-se-iam no conceito jurídico de família todos os tipos de relações, sejam elas, homo ou heterossexuais. 
A exemplo de outros países que assim o fizeram, é urgente que se preencha essa lacuna jurídica, regulamentando as uniões homoeróticas, a fim de assegurar o respeito à Constituição e aos direitos humanos.

Seguindo este caminho, a Lei n. 11.340/06, que cria mecanismos para coibir a violência doméstica e familiar contra a mulher, estende às relações homoafetivas, em seu art. $5^{\circ}$, o conceito de família:

O casamento, que hoje é considerado por muitos uma instituição falida, caminhando para formas mais inclusivas, pode ser, para os homossexuais, além de um direito, um poderoso instrumento de eliminação da discriminação e de estigma social negativo.

\section{Conclusão}

Diante de todo o exposto podemos concluir que:

A sociedade brasileira é dinâmica e abarca uma diversidade de relações. O Direito brasileiro deve acompanhar as mudanças sociais e contemplar, sempre que possível, essa diversidade.

Querer curar ou modificar um homossexual é ignorância do atual estágio das ciências médicas e biológicas e mero preconceito, e sendo a orientação sexual um dos componentes da sexualidade humana, ela é uma característica perfeitamente natural e o desafio que se impõe é reaprender a lidar com ela, reconhecendo-a tanto social como juridicamente, afastando de uma vez por todas os preconceitos que ainda insistem em envolver a questão.

A opressão sofrida pelos homossexuais é injusta, pois estes são quase que obrigados a "trocar" de identidade perante a sociedade, mentindo para si e para todos, sobre uma coisa tão essencial a qualquer ser humano que é a de viver, não apenas a sua sexualidade, mas também a sua afetividade.

O Direito que outrora instituiu a escravidão, e que até a bem pouco tempo atrás, considerava as mulheres relativamente incapazes, continua hoje, a servir de instrumento de opressão às minorias sexuais.

O direito à orientação sexual é uma questão de direitos humanos.

O direito à livre orientação sexual é um direito personalíssimo, e, portanto, irrenunciável, inalienável, intransmissível e imprescritível.

$\mathrm{O}$ constituinte assegurou o direito à felicidade, entendido este como a forma livre de condução da vida do indivíduo dentro de seu contexto social. 
Nos mesmos moldes em que ocorreu nos casos de uniões heterossexuais antes do advento das leis ns. 8.971/94 e 9.278/96, as uniões homoeróticas têm sido consideradas, pela jurisprudência, sociedade de fato a ensejar partilha do bem comum. Aos poucos, as decisões judiciais começam a reconhecer as uniões homoafetivas como entidade familiar.

A família é a base da estrutura social e sede da plenitude do bem-estar do ser humano e deve abranger pelo menos duas pessoas que se unem com o propósito de manutenção desse vínculo afetivo, independente de serem de sexo diverso, tenham ou-não prole.

Se a prole ou a capacidade procriativa não são essenciais para que o relacionamento de duas pessoas mereça proteção legal, não se justifica deixar ao desabrigo do conceito de família a convivência entre pessoas do mesmo sexo.

Passando, duas pessoas ligadas por um vínculo afetivo, a manter uma relação duradoura, pública e contínua, como se casados fossem, formam um núcleo familiar à semelhança do casamento, independente do sexo a que pertencem.

Abstraindo-se o sexo dos conviventes, nenhuma diferença há entre as relações homo e heterossexuais, pois existe uma semelhança no essencial, a identidade de motivos entre os dois casos.

Sendo assim, atendidos os requisitos legais para a configuração de união estável, é necessário que sejam conferidos direitos e impostas obrigações, independente da identidade ou diversidade do sexo dos conviventes, pois, ao não assegurar qualquer garantia nem outorgar quaisquer direitos às uniões homoeróticas, há infringência do princípio da igualdade e revela-se discriminação sexual.

Portanto, utilizando-se de uma interpretação analógica, atualizada, sistematizada e humana, as leis reguladoras do relacionamento entre homem e uma mulher, enquanto não-reformada a legislação, substituindo "homem e mulher" por "pessoas", podem e devem ser aplicadas às relações homoeróticas, já que é vedada a interpretação de forma restritiva e excludente.

A exemplo de outros países que assim o fizeram, é urgente que se preencha essa lacuna jurídica, regulamentando as uniões homoafetivas, a fim de assegurar o respeito à Constituição e aos direitos humanos.

São Paulo, março de 2007. 
Referências

ALEXY, Robert. Teoria de los derechos fundamentales. Madri: Centro de Estudios Constitucionales, 1997.

ARAÚJO, Luiz Alberto David. A proteção constitucional do transexual. São Paulo: Saraiva, 2000.

ARANHA, Maria Lúcia de Arruda; MARTINS, Maria Helena Pires. Filosofando: introdução à filosofia. $2^{\mathrm{a}}$ ed. São Paulo: Moderna, 1993.

AZEVEDO, Álvaro Villaça de. Estatuto da família de fato. São Paulo: Jurídico Brasileira, 2001. . União entre pessoas do mesmo sexo. Revista da Faculdade de Direito, São Paulo, v. 94, p. $12-31$, jan./dez. 1999.

BACILA, Carlos Roberto. Estigmas: um estudo sobre os preconceitos. Rio de Janeiro: Lumen Juris, 2005.

BALDI, César Augusto (Org.). Direitos humanos na sociedade cosmopolita. Rio de Janeiro: Renovar, 2004.

BARROS, Sérgio Resende de. Direitos humanos da família: dos fundamentais aos operacionais. In: GROENINGA, Giselle Câmara; PEREIRA, Rodrigo da Cunha (Orgs.). Direito da família e psicanálise: rumo uma nova epistemologia. Rio de Janeiro: Imago, 2003.

BIANCARELLI, Aureliano. Pais gays criam filhos sem preconceito. Folha de S.Paulo, São Paulo, 31.03.2002.

BOBBIO, Norberto. A era dos direitos. Tradução de Carlos Nelson Coutinho. 2. ed. Rio de Janeiro: Elsevier, 2004.

BOFF, Leonardo. A águia e a galinha: uma metáfora da condição humana. 30. ed. Petrópolis: Vozes, 1999.

BOSWELL, John. Christianity, social tolerance, and homosexuality. Chicago: The University of Chicago Press, 1981. . Same-sex unions in premodern Europe. New York: Vintage, 1995.

BOUCAULT, Carlos Eduardo de Abreu; ARAÚJO, Nadia de (Orgs.). Os direitos humanos e o direito internacional. Rio de Janeiro: Renovar, 1999.

BOUDON, Raymond; BOURRICAUD, François. Sociologia. Tradução de Maria Lúcia Guedes Alcofarado e Durval Ártico. São Paulo: Ática, 1993. 
BURGOS, Patrícia. Espanha faz $1^{\circ}$ casamento de gays brasileiros. Folha de S.Paulo, São Paulo, 14.02.2006.

CANOTILHO, José Joaquim Gomes. Direito constitucional e teoria da Constituição. 2. ed. Coimbra: Almedina, 1998.

CARBONELL, Miguel. Estudio preliminar. La igualdad y los derechos humanos. El principio constitucional de igualdad: Llcturas de introducción. México: Comisión Nacional de Los Derechos Humanos, 2003.

COMPARATO, Fábio Konder. Afirmação histórica dos direitos humanos. 4. ed. rev. e atual. São Paulo: Saraiva, 2005.

. Direito público e privado. São Paulo: Saraiva, 1996.

COSTA, Jurandir Freire. A inocência e o vício: estudos sobre o homerotismo. Rio de Janeiro: Relume-Dumará, 1992

CZAJKOWSKI, Rainer. Reflexos jurídicos das uniões homossexuais. Jurisprudência Brasileira: cível e comércio, Curitiba, n. 176. p. 95-107, 1995.

DAGNESE, Napoleão. Cidadania no armário: uma abordagem sócio-jurídica acerca da homossexualidade. São Paulo: LTr, 2000.

DAHER, Marluci Pestana. Uniões homossexuais. Juris Síntese: legislação e jurisprudência, São Paulo, n. 18, jul./ago. 1999.

DIAS, Maira Berenice. Homoafetividade: o que diz a Justiça!: as pioneiras decisões do Tribunal de Justiça do Rio Grande do Sul que reconhecem direitos às uniões homossexuais. Porto Alegre: Livraria do Advogado Editora, 2003.

. Novos tempos, novos termos. Disponível em: <http://www.mariaberenice.com.br/site/ content.php? contid=467\&isPopUp=true $>$. Acesso em: 04 out 2006.

. União homossexual: o preconceito \& a justiça. Porto Alegre: Livraria do Advogado, 2000.

; PEREIRA, Rodrigo da Cunha (Orgs.). Direito de família e o novo civil brasileiro. Belo Horizonte: Del Rey, 2001.

DI GIORGI, Beatriz; CAMPILONGO, Celso Fernandes; PIOVESAN, Flávia. Direito, cidadania e justiça: ensaios sobre lógica, interpretação, teoria, sociologia e filosofia jurídica. São Paulo: Revista dos Tribunais, 1992. 
DINIZ, Maria Helena. Dicionário jurídico. São Paulo: Saraiva, 1998.

DORIN, Lannoy. Enciclopédia de Psicologia Contemporânea. São Paulo: Iracema, 1977.

DOVER, Kenneth James. A homossexualidade na Grécia antiga. Tradução de Luís Sérgio Frausz. São Paulo: Nova Alexandria, 1994.

ENGELS, Friedrich. A origem da família, da prorpiedade privada e do Estado. Tradução de Leandro Konder. 12. ed. Rio de Janeiro: Bertrand, 1991.

FACHIN, Luiz Edson. Elementos críticos do direito de família. Rio de Janeiro: Renovar, 1999.

FOUCAULT, Michel. História da sexualidade I: a vontade de saber. Tradução de Maria Thereza da Costa Albuquerque e J.A Guilhon Albuquerque. 11. ed. Rio de Janeiro: Graal, 1993.

FRANÇA, Genival Veloso de. Medicina legal. 4. ed. Rio de Janeiro: Guanabara Koogan, 1995.

FRISCHEISEN, Luiza Cristina Fonseca. Construção da igualdade e o sistema de justiça no Brasil: alguns caminhos e possibilidades. 2004. Tese (Doutorado) - Faculdade de Direito, Universidade de São Paulo, São Paulo.

FRY, Peter; MACRAE, Edward. O que é homossexualidade. 7. ed. São Paulo: Brasiliense, 1991. GAGLIANO, Pablo Stolze. Novo curso de direito civil. 7. ed. São Paulo: Saraiva. 2006.

GAMA, Guilherme Calmon Nogueira da. O companheirismo: uma espécie de família. São Paulo: RT, 1998.

. A união civil entre pessoas do mesmo sexo. Revista de Direito Privado, v. 2, p. 31-42. 1999.

GÓIS, Antônio; TÓFOLI, Daniela. "Gay família" é maioria na parada de SP. Folha de S.Paulo, 16.06.2006

GOMES, Joaquim B. Barbosa. Ação afirmativa \& princípio constitucional da igualdade (o direito como instrumento de transformação social. A Experiência dos EUA). Rio de Janeiro: Renovar, 2001 .

GUILHERME, Luiz Fernando do Vale de Almeida. União estável entre homossexuais no direito brasileiro e no direito comparado. Revista da Escola Paulista de Magistratura, São Paulo, ano 4, n. 2, p. 150-171, jul./dez. 2003.

GREEN, James Naylor. Além do Carnaval: a homossexualidade masculina no Brasil do século XX. Tradução de Cristina Fino e Cássio Arantes Leite. São Paulo: Unesp, 2000. 
GROENINGA, Giselle Câmara; PEREIRA, Rodrigo da Cunha (Orgs.). Direito da familia e psicanálise: rumo uma nova epistemologia. Rio de Janeiro: Imago, 2003.

HALLIFAX, Noel . Libertação gay e luta pelo socialismo. Disponível em: $<$ htttp://members.tripod. com/ socialista/textos/homo.html>. Acesso em: 06/06/2000.

HIRONAKA, Giselda Maria Fernandes Novaes. Família e casamento em evolução. Revista do Advogado, São Paulo, n. 62, p 16-24, mar. 2001.

HOUAISS, Antonio; VILAR, Mauro de Sales. Dicionário Houaiss da Língua Portuguesa. Rio de Janeiro: Objetiva, 2001.

LÔBO, Paulo Lins Netto. Entidades familiares constitucionalizadas: para além do numerus clausus. In: III CONGRESSO BRASILEIRO DE DIREITO DE FAMÍLIA. Família e cidadania: o novo CCB e a vacatio legis. Belo Horizonte: Del Rey, 2002.

LOPES, José Reinaldo de Lima. O direito ao reconhecimento para gays e lésbicas. Revista Internacional de Direitos Humanos, São Paulo, ano. 2, n. 2, 2005.

. Direitos humanos e tratamento igualitário: questões de impunidade, dignidade e liberdade. Revista Brasileira de Ciências Sociais, v. 15, n. 42, p. 77-100, dez. 2005.

. As palavras e a lei: direito, ordem e justiça na história do pensamento jurídico moderno. São Paulo: Ed. 34/Edesp, 2004.

MACEDO, Daniela Cristina Alaniz; ALEXANDRE, Eliane Sobrinho. Uma visão jurídica e social da homossexualidde. Londrina: Eduel, 2003.

MACIEL, Débora Alves; KOERNER. André. Sentidos da judicialização da política: duas análises. Lua Nova, São Paulo, n. 57, p. 113-133, 2002.

MATOS, Ana Carla Harmatuik. União entre pessoas do mesmo sexo: aspectos jurídicos e sociais. Belo Horizonte: Del Rey, 2004.

MELlo, Celso Antônio Bandeira de. Conteúdo jurídico do princípio da igualdade. 3. ed. São Paulo: Malheiros, 2006.

MONTORO, André Franco. Estudos de filosofia do direito. 2. ed. São Paulo: Saraiva, 1995.

MOTT, Luis. O que todo cristão deve saber sobre homossexualidade. Disponível em: $<\mathrm{http}: / / \mathrm{www}$. ggb.org.br/cristão.html>. Acesso em: 09 mar. 2000. 
MOTTA, Carlos Dias. Uma teoria geral dos princípios jurídicos aplicada ao direito matrimonial. 2003. Tese (Doutorado) - Faculdade de Direito, Universidade de São Paulo, São Paulo.

NOGUEIRA, Luiz Fernando Valladão. Sociedade de fato entre pessoas do mesmo sexo independente de qualquer inovação legal. Juris Síntese: legislação e jurisprudência, São Paulo, n. 18. jul./ago. 1999.

OLIVEIRA, Guilherme de. Sobre a verdade e a ficção no direito de família. Boletim da Faculdade de Direito, Coimbra, n. 51, p. 272-83, 1975.

OLIVEIRA, José Sebastião de. Fundamentos constitucionais do direito de família. São Paulo: Revista dos Tribunais, 2002.

PEREIRA, Mirian Freire. As inovações constitucionais no direito de família. 1993. Dissertação (Mestrado) - Faculdade de Direito, Universidade de São Paulo, São Paulo.

PEREIRA, Rodrigo da Cunha (Org.). Afeto, ética, família e o novo código civil. Belo Horizonte: Del Rey, 2004.

. Direito de família: uma abordagem psicanalítica. 2. ed. rev. atual. ampl. Belo Horizonte: Del Rey, 2003.

PIOVESAN, Flávia. Direitos humanos e o direito constitucional internacional. 7. ed. rev. ampl. e atual. São Paulo: Saraiva, 2006.

. Reforma do Judiciário e Direitos Humanos. In: TAVAREZ, André Ramos; LENZA, Pedro; ALARCÓN, Pietro de Jesus Lora (Orgs.). Reforma do Judiciário: analisada e comentada. São Paulo: Método, 2005.

PRADO, Danda. O que é família. 4. ed. São Paulo: Brasiliense, 1984.

RAMOS, André de Carvalho. Teoria geral dos direitos humanos na ordem internacional. Rio de Janeiro: Renovar, 2005.

REALE, Miguel. Estudos de filosofia e ciência do direito. São Paulo: Saraiva, 1978. . Filosofia do direito. 13. ed. São Paulo: Saraiva, 1990.

REIS, Dagma Paulino dos. O homossexualismo e a discriminação no direito e na vida social e familiar. Revista Juridica, Porto Alegre, v. 47, n. 269, p. 15-25, mar. 2000.

ROBLES, Gregório. Os direitos fundamentais e a ética na sociedade atual. Tradução de Roberto Barbosa Alves. Barueri: Manole, 2005. 
RIOS, Roger Raupp. A homossexualidade no Direito. Porto Alegre: Livraria do Advogado, Esmafe, 2001.

. Princípio da igualdade e a discriminação por orientação sexual: a hossexualidade no direito brasileiro e norte-americado. São Paulo: Revista dos Tribunais; 2002.

SALET, Ingo Wolfgang. Dignidade da pessoa humana e direitos fundamentais na Constituição Federal de 1988. 3. ed. rev. atual. e ampl. Porto Alegre: Livraria do Advogado, 2004.

SÉGUIN, Élida (Org.). Direito das Minorias. Rio de Janeiro: Forense, 2001.

SEVERINO, Antônio Joaquim. Metodologia do trabalho cientifico. 22. ed. rev. e ampl. São Paulo: Cortez, 2002.

SILVA, José Afonso da. Curso de direito constitucional positivo. 16. ed. São Paulo: Malheiros, 1999.

SUANNES, Adauto. Concubinato e homossexualismo. Revista Literária de Direito, n. 15, 1997.

SULLIVAN, Andrew. Praticamente normal: uma discussão sobre o homossexualismo. Tradução Isa Mara Lando. São Paulo: Companhia das Letras, 1996.

SUTTER, Matilde Josefina. Determinação e mudança de sexo: aspectos médicos-legais. São Paulo: Revista dos Tribunais, 1993.

TAVARELA, Glauber Moreno. União civil entre pessoas do mesmo sexo. Rio de Janeiro: Forense, 2004. TRINDADE, Antonio Augusto Cançado. A proteção dos direitos humanos nos planos nacional e internacional e internacional. Perspectivas brasilerias. Brasília: Instituto Interamericano de Derechos Humanos, 1992.

TUGENDHAT, Ernest. Lições sobre ética. Tradução grupo de doutorandos do curso de pós graduação em Filosofia da Universidade do Rio Grande do Sul; revisão e organização da tradução Ernildo Stein e Ronai Rocha. Petrópolis: Vozes, 1996.

VIANA, Márcio Túlio; RENAULT, Luiz Otávio Linhares (Orgs.). Discriminação: estudos. São Paulo: LTr, 2000.

WASSERMANN, Rogério. Ser gay é crime em 70 países, diz Anistia. Folha de S.Paulo, 23.06.2001.

WOLKMER, Antonio Carlos (Org.). Direitos humanos e filosofia jurídica na América Latina. Rio de Janeiro: Lumen Juris, 2004. 